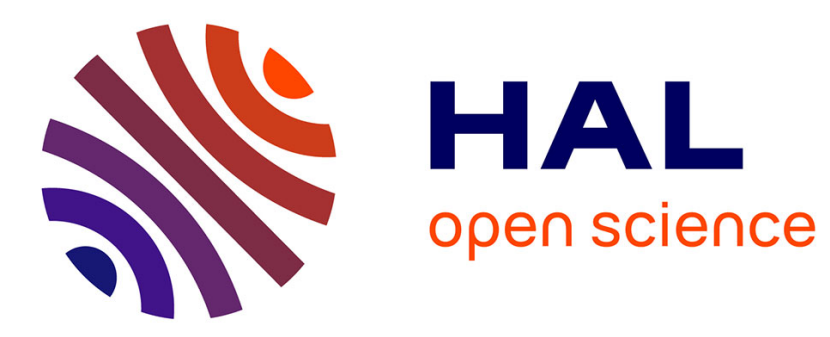

\title{
OTX2 Homeoprotein Functions in Adult Choroid Plexus
}

Anabelle Planques, Vanessa Oliveira Moreira, David Benacom, Clémence

Bernard, Laurent Jourdren, Corinne Blugeon, Florent Dingli, Vanessa

Masson, Damarys Loew, Alain Prochiantz, et al.

\section{To cite this version:}

Anabelle Planques, Vanessa Oliveira Moreira, David Benacom, Clémence Bernard, Laurent Jourdren, et al.. OTX2 Homeoprotein Functions in Adult Choroid Plexus. International Journal of Molecular Sciences, 2021, 22 (16), pp.8951. 10.3390/ijms22168951 . hal-03428847

\section{HAL Id: hal-03428847 https://hal.science/hal-03428847}

Submitted on 15 Nov 2021

HAL is a multi-disciplinary open access archive for the deposit and dissemination of scientific research documents, whether they are published or not. The documents may come from teaching and research institutions in France or abroad, or from public or private research centers.
L'archive ouverte pluridisciplinaire HAL, est destinée au dépôt et à la diffusion de documents scientifiques de niveau recherche, publiés ou non, émanant des établissements d'enseignement et de recherche français ou étrangers, des laboratoires publics ou privés. 


\title{
Article
}

\section{OTX2 Homeoprotein Functions in Adult Choroid Plexus}

\author{
Anabelle Planques ${ }^{1,+} \mathbb{D}$, Vanessa Oliveira Moreira ${ }^{1,+} \mathbb{D}$, David Benacom ${ }^{1}$, Clémence Bernard ${ }^{1}(\mathbb{D}$, \\ Laurent Jourdren $^{2}{ }^{(D}$, Corinne Blugeon ${ }^{2}$, Florent Dingli ${ }^{3}$, Vanessa Masson ${ }^{3} \mathbb{D}$, Damarys Loew $^{3}{ }^{(D)}$, \\ Alain Prochiantz ${ }^{1,4}$ and Ariel A. Di Nardo ${ }^{1, *}$
}

1 Centre for Interdisciplinary Research in Biology (CIRB), Collège de France, CNRS UMR7241, INSERM U1050, Labex MemoLife, PSL University, 75005 Paris, France; planques.anabelle@gmail.com (A.P.); vanessa.oliveira-moreira@college-de-france.fr (V.O.M.); david.benacom@college-de-france.fr (D.B.); clemence.bernard@kcl.ac.uk (C.B.); alain.prochiantz@college-de-france.fr (A.P.)

2 Genomics Core Facility, Institut de Biologie de l'ENS (IBENS), Département de Biologie, École Normale Supérieure, CNRS, INSERM, PSL University, 75005 Paris, France; jourdren@biologie.ens.fr (L.J.); blugeon@biologie.ens.fr (C.B.)

3 Laboratoire de Spectrométrie de Masse Protéomique, Centre de Recherche, Institut Curie, CEDEX 05, 75248 Paris, France; florent.dingli@curie.fr (F.D.); vanessa.masson@curie.fr (V.M.); damarys.loew@curie.fr (D.L.)

4 Institute of Neurosciences, Chinese Academy of Sciences, 320 Yue Yang Road, Shanghai 200031, China

* Correspondence: ariel.dinardo@college-de-france.fr

+ These authors contributed equally.

Citation: Planques, A.; Oliveira Moreira, V.; Benacom, D.; Bernard, C.; Jourdren, L.; Blugeon, C.; Dingli, F.;

Masson, V.; Loew, D.; Prochiantz, A.; et al. OTX2 Homeoprotein Functions in Adult Choroid Plexus. Int. J. Mol. Sci. 2021, 22, 8951. https://doi.org/ $10.3390 /$ ijms22168951

Academic Editor: Yuzuru Imai

Received: 19 July 2021

Accepted: 17 August 2021

Published: 19 August 2021

Publisher's Note: MDPI stays neutral with regard to jurisdictional claims in published maps and institutional affiliations.

Copyright: (c) 2021 by the authors. Licensee MDPI, Basel, Switzerland. This article is an open access article distributed under the terms and conditions of the Creative Commons Attribution (CC BY) license (https:/ / creativecommons.org/licenses/by/ $4.0 /)$.

\begin{abstract}
The choroid plexus is an important blood barrier that secretes cerebrospinal fluid, which essential for embryonic brain development and adult brain homeostasis. The OTX2 homeoprotein is a transcription factor that is critical for choroid plexus development and remains highly expressed in adult choroid plexus. Through RNA sequencing analyses of constitutive and conditional knockdown adult mouse models, we reveal putative functional roles for OTX2 in adult choroid plexus function, including cell signaling and adhesion, and show that OTX2 regulates the expression of factors that are secreted into the cerebrospinal fluid, notably transthyretin. We also show that Otx2 expression impacts choroid plexus immune and stress responses, and affects splicing, leading to changes in the mRNA isoforms of proteins that are implicated in the oxidative stress response and DNA repair. Through mass spectrometry analysis of OTX2 protein partners in the choroid plexus, and in known non-cell-autonomous target regions, such as the visual cortex and subventricular zone, we identify putative targets that are involved in cell adhesion, chromatin structure, and RNA processing. Thus, OTX2 retains important roles for regulating choroid plexus function and brain homeostasis throughout life.
\end{abstract}

Keywords: homeodomain; transcription factor; splicing; homeostasis

\section{Introduction}

The choroid plexus (ChP) epithelium is located in the brain ventricles and secretes cerebrospinal fluid (CSF) containing molecules that regulate embryonic brain development and adult brain homeostasis [1]. The ventricular system includes the two lateral ventricles (LVs) in each cerebral hemisphere, the central third ventricle of the forebrain diencephalon, and the central fourth ventricle $(4 \mathrm{~V})$ in the hindbrain. This system is interconnected, allowing for CSF flow throughout, and is also connected via the $4 \mathrm{~V}$ with the central canal of the spinal cord. The OTX2 homeoprotein transcription factor is critical for ChP embryonic development and functions [2]. Interestingly, temporal and spatial heterogeneity is evident, as the role of OTX2 evolves during development and differs between ChPs. For example, in late embryonic development, OTX2 is required for the maintenance of the $4 \mathrm{~V} \mathrm{ChP,} \mathrm{but} \mathrm{not}$ LV ChP [2]. Indeed, embryonic LV and 4V ChP show distinct gene expression patterns [3,4], suggesting different signaling properties. In the adult, OTX2 is still strongly expressed in the $\mathrm{ChP}$ [5], but its role has not been thoroughly investigated. 
Homeoproteins are transcription factors that are important for embryonic development, and adult homeostasis and cell survival, and several homeoproteins have functions beyond transcription, including translation regulation, DNA repair, and signal transduction [6-8]. While several studies have explored the molecular partners and transcriptional targets of OTX2, they were typically restricted to embryonic contexts [9-13]. In the adult mouse, recent analyses of OTX2 protein and DNA targets have focused on the retina [14,15], visual cortex [16,17], and ventral tegmental area [18]. These studies revealed targets that are implicated in transcription, epigenetics, signal transduction, and homeostasis, and confirmed that OTX2 not only binds multiple sites across DNA, but also interacts with the machinery for RNA processing, export, and translation. To examine the role of OTX2 in adult $\mathrm{ChP}$, we use a mouse model for constitutive heterozygous Ot $x 2$ knockdown, and a model for the ChP-specific conditional knockdown of Otx2. Through transcriptomic analysis of LV and $4 \mathrm{~V} \mathrm{ChPs}$, we reveal dysregulation of cell adhesion and membrane proteins, secreted factors, signaling factors, immune response, and oxidative stress response. Through mass spectrometry analysis of OTX2 partners in ChP and non-cell-autonomous target regions $[19,20]$, including the ventricular-subventricular zone (SVZ), rostral migratory stream (RMS), and visual cortex (VCx), we identified putative targets that are involved in cell adhesion, chromatin structure, and RNA processing. We also performed splice variant analysis and confirmed, by acute viral shRNA-Otx2 knockdown in the ChP of adult wildtype mice, that OTX2 can regulate the isoform distribution of genes involved in stress response and DNA repair. Taken together, our findings suggest that OTX2 has direct roles in ChP signaling, barrier, and surveillance functions.

\section{Results and Discussion}

\subsection{Conditional and Constitutive Knockdown of Otx2 in Adult ChP}

OTX2 is a key regulator of $\mathrm{ChP}$ and brain development, but its role in adult $\mathrm{ChP}$ is not well known. To gain an insight into its adult $\mathrm{ChP}$ functions, we performed RNA sequencing analysis with two mouse models. The first consisted of 3-month-old Otx $2^{l o x / l o x}$ mice for the conditional knockdown of $\mathrm{Otx2}$, specifically in the $\mathrm{ChP}$, through intracerebroventricular (icv) injections of Cre-Tat recombinant protein, which leads to a $\sim 50 \%$ reduction in (mRNA) Otx2 and a $>70 \%$ reduction in OTX2 protein levels [5]. The ChPs from LV and $4 \mathrm{~V}$ were dissected separately from both Cre-Tat-injected $\left(\mathrm{Cre}^{+} \mathrm{Otx} 2^{l o x / l o x}\right)$ and control vehicle-injected mice $\left(\mathrm{Veh}^{+} \mathrm{Otx} 2^{\text {lox } / l o x}\right)$. While the bilateral stereotaxic injections of vehicle or Cre-Tat are performed only in the lateral ventricles, we have previously shown, with this protocol, that the level of Otx2 knockdown in $4 \mathrm{~V} \mathrm{ChP} \mathrm{is} \mathrm{proportional} \mathrm{to} \mathrm{that} \mathrm{in} \mathrm{LV} \mathrm{ChP} \mathrm{[19].} \mathrm{Indeed,}$ we found a $48 \%$ decrease in (mRNA) Otx2 (exon 2) in the LV ChP (vehicle, 7924 mean reads; Cre-Tat 4143 mean reads), and a 39\% decrease in $4 \mathrm{~V} \mathrm{ChP} \mathrm{(vehicle,} 6898$ mean reads; Cre-Tat 4169 mean reads). The second model consisted of $O t x 2^{+/ G F P}$ mice as a constitutive heterozygous knockout mutant, with $\sim 50 \%$ Otx 2 protein levels compared to the wildtype [21]. For this model, given the significant overlap in gene expression changes in the $\mathrm{LV}$ and $4 \mathrm{~V}$ of $\mathrm{Cre}^{+} \mathrm{Ot} x 2^{\text {lox/lox }}$ mice (see below), only the $4 \mathrm{~V} \mathrm{ChPs}$ were dissected and pooled from 3-month-old wildtype and mutant mice. We found a 38\% decrease in (mRNA) Otx2 (exon 2) in 4V ChP (wildtype, 6399 mean reads; Otx2 ${ }^{+/ G F P} 3957$ mean reads).

The transcriptomics analysis of adult $\mathrm{ChP}$ showed highly expressed genes that are involved in energy metabolism, protein signaling, solute transport, cell adhesion, the cytoskeleton, and chaperone activity (Table 1). While not in the same order of gene expression level, this list compares favorably with those obtained from other $\mathrm{ChP}$ transcriptomics studies $[4,22,23]$. The conditional adult mouse knockdown of Otx2 led to significant changes in the expression of 375 genes in LV ChP and 808 genes in $4 \mathrm{~V} \mathrm{ChP} \mathrm{(p-adj<0.05).} \mathrm{The} \mathrm{top}$ ten upregulated and downregulated genes show a range of functions, including solute transport, signaling, immune response, and trafficking (Table 2). While there is a significant overlap in the altered gene expression between the ChPs (Figure 1A), the $4 \mathrm{~V} \mathrm{ChP} \mathrm{seems}$ to be more susceptible to loss of Otx2 activity. The response to Otx2 knockdown results in a rather even distribution of upregulation (522 genes) and downregulation (392 genes) 
when grouping both $4 \mathrm{~V}$ and LV ChPs. However, ontological analysis reveals that the downregulated genes in both ChPs show higher levels of enrichment in significantly altered classes, suggesting that upregulated genes have more broadly distributed functions (Figure 1B,C). Interestingly, both ChPs have similar ontology enrichment in downregulated genes, indicating that $\mathrm{Ot} x 2$ is generally important for the expression of membrane proteins, glycoproteins, signaling proteins, and cell adhesion proteins. While some of these functions are recapitulated in the upregulated genes, there is much more heterogeneity between the LV and $4 \mathrm{~V} \mathrm{ChP.} \mathrm{The} \mathrm{LV} \mathrm{ChP} \mathrm{shows} \mathrm{more} \mathrm{immune} \mathrm{response} \mathrm{ontology,} \mathrm{while}$ the $4 \mathrm{~V} \mathrm{ChP} \mathrm{shows} \mathrm{more} \mathrm{signaling-related} \mathrm{ontology.} \mathrm{This} \mathrm{suggests} \mathrm{that} \mathrm{conditional} \mathrm{knock-}$ down of Otx2 leads to altered $\mathrm{ChP}$ barrier function and $\mathrm{ChP}$ signaling, and can impact immune responses.

Table 1. Top 50 genes expressed in lateral ventricle (LV) and fourth ventricle (4V) choroid plexus (ChP). Significantly different expression between structures is indicated in bold.

\begin{tabular}{|c|c|c|c|c|c|c|}
\hline Gene Symbol & Function & $\begin{array}{c}\text { Mean Reads } \\
\text { Combined }\end{array}$ & $\begin{array}{l}\text { Mean Reads } \\
\text { 4V ChP }\end{array}$ & $\begin{array}{l}\text { Mean Reads } \\
\text { LV ChP }\end{array}$ & $\begin{array}{l}\text { Fold Change } \\
\text { LV vs. } 4 \mathrm{~V}\end{array}$ & $p$-adj \\
\hline Ttr & $\mathrm{T}_{4}$ and retinol transport & $2,623,541$ & $2,348,304$ & $2,898,779$ & 1.2 & 0.4700 \\
\hline Enpp 2 & Extracellular signaling & 593,932 & 612,769 & 575,094 & 0.94 & 1 \\
\hline Malat1 & RNA processing & 112,726 & 157,395 & 68,058 & 0.43 & 0.1482 \\
\hline Apoe & Lipid transport & 64,482 & 54,600 & 74,365 & 1.4 & 0.7231 \\
\hline Trpm3 & Cation channel & 39,627 & 46,150 & 33,105 & 0.72 & 0.1606 \\
\hline$B s g$ & Cell adhesion & 49,354 & 41,701 & 57,007 & 1.4 & 0.5023 \\
\hline Kl & Cell signaling & 45,044 & 40,667 & 49,422 & 1.2 & 0.4792 \\
\hline$A b h d 2$ & Lipid metabolism & 41,094 & 36,405 & 45,783 & 1.3 & 0.2413 \\
\hline AY036118 & Hemopoiesis & 25,992 & 33,903 & 18,081 & 0.53 & 1 \\
\hline Slc4a10 & Solute transport & 30,242 & 30,563 & 29,920 & 0.98 & 1 \\
\hline Psap & Trophic, metabolism & 33,695 & 28,768 & 38,623 & 1.3 & 0.0646 \\
\hline Igfbp2 & IGF-binding & 25,336 & 28,556 & 22,117 & 0.77 & 0.4457 \\
\hline Hspa5 & ER chaperone & 25,426 & 24,960 & 25,891 & 1.0 & 1 \\
\hline F5 & Hemostasis & 25,758 & 24,672 & 26,843 & 1.1 & 0.9813 \\
\hline Slc12a2 & Solute transport & 23,869 & 24,279 & 23,459 & 0.97 & 1 \\
\hline Ctsd & APP processing & 28,200 & 23,672 & 32,728 & 1.4 & 0.0423 \\
\hline Prlr & Hormone receptor & 27,452 & 22,728 & 32,176 & 1.4 & 0.7565 \\
\hline Atp1a1 & Ion transport & 22,896 & 22,067 & 23,724 & 1.1 & 1 \\
\hline Clu & Extracellular chaperone & 26,747 & 21,750 & 31,744 & 1.5 & 0.0323 \\
\hline$A p p$ & Cell adhesion, signaling & 19,290 & 21,197 & 17,383 & 0.82 & 0.4130 \\
\hline Cntn1 & Cell adhesion & 25,888 & 21,017 & 30,759 & 1.5 & 0.0175 \\
\hline Atp $2 b 3$ & Ion transport & 20,580 & 19,745 & 21,415 & 1.1 & 1 \\
\hline Ahcyl2 & Solute transport & 20,726 & 19,427 & 22,025 & 1.1 & 0.8161 \\
\hline $\operatorname{Igf2}$ & Growth hormone & 24,978 & 18,973 & 30,984 & 1.6 & 0.0123 \\
\hline Hsp90b1 & Chaperone & 18,816 & 18,514 & 19,117 & 1.0 & 1 \\
\hline Sptbn1 & Cytoskeleton & 18,883 & 18,276 & 19,490 & 1.1 & 1 \\
\hline Cpe & Prohormone processing & 17,182 & 17,449 & 16,916 & 0.97 & 1 \\
\hline Car12 & Metabolism & 18,529 & 17,277 & 19,782 & 1.1 & 0.7979 \\
\hline Clic6 & Ion channel & 16,953 & 16,432 & 17,473 & 1.1 & 1 \\
\hline Strip2 & Cytoskeleton & 14,776 & 16,187 & 13,366 & 0.83 & 0.4745 \\
\hline Timp3 & Collagenase inhibitor & 18,530 & 15,562 & 21,499 & 1.4 & 0.0292 \\
\hline Itpr1 & $\mathrm{ER} \mathrm{Ca}^{2+}$ release & 16,252 & 15,546 & 16,957 & 1.1 & 0.9741 \\
\hline Kcne2 & Potassium channel & 13,861 & 15,416 & 12,305 & 0.8 & 0.8581 \\
\hline Cgnl1 & Cell adhesion & 15,183 & 15,292 & 15,073 & 0.99 & 1 \\
\hline Gpm6a & Membrane structure & 22,456 & 15,181 & 29,732 & 2.0 & 0.0000 \\
\hline Slc $4 a 2$ & Solute carrier & 15,501 & 14,912 & 16,090 & 1.1 & 1 \\
\hline Atp5a1 & Metabolism & 15,922 & 14,766 & 17,078 & 1.2 & 0.7456 \\
\hline Nsg2 & Vesicle trafficking & 15,587 & 14,669 & 16,506 & 1.1 & 0.8949 \\
\hline $\mathrm{Zbtb20}$ & Transcription factor & 12,600 & 14,603 & 10,597 & 0.73 & 0.5636 \\
\hline Stk39 & Stress response & 14,417 & 14,507 & 14,326 & 0.99 & 1 \\
\hline Tmem72 & & 14,821 & 14,343 & 15,298 & 1.1 & 1 \\
\hline Cab39l & Cell polarity & 15,438 & 14,311 & 16,565 & 1.2 & 0.8214 \\
\hline Nedd4 & Ubiquitination & 15,837 & 14,272 & 17,402 & 1.2 & 0.4738 \\
\hline Macf1 & Cytoskeleton & 12,704 & 14,027 & 11,382 & 0.81 & 0.5999 \\
\hline Vat1l & & 14,589 & 13,983 & 15,196 & 1.1 & 1 \\
\hline Hsp90ab1 & Chaperone & 14,368 & 13,756 & 14,979 & 1.1 & 1 \\
\hline Calr & Chaperone & 13,889 & 13,606 & 14,171 & 1.0 & 1 \\
\hline $\mathrm{Htr} 2 \mathrm{c}$ & Serotonin receptor & 13,453 & 13,343 & 13,564 & 1.0 & 1 \\
\hline Slc $5 a 3$ & Solute transport & 11,648 & 13,281 & 10,015 & 0.75 & 0.0914 \\
\hline Sptan1 & Cytoskeleton, Secretion & 11,913 & 13,161 & 10,665 & 0.81 & 0.3292 \\
\hline
\end{tabular}


Table 2. Top 10 differentially expressed genes in choroid plexus of $\mathrm{Cre}^{+} \mathrm{Ot} x 2^{\text {lox } / l o x}$ mice. Genes in fourth ventricle with * are also deregulated upon embryonic Ot $x 2$ knockdown in the hindbrain choroid plexus [2].

\begin{tabular}{|c|c|c|c|c|}
\hline Gene Symbol & Mean Reads Vehicle & Mean Reads Cre-Tat & Fold Change & $p$-adj \\
\hline \multicolumn{5}{|c|}{ Upregulated in lateral ventricle $\mathrm{ChP}$} \\
\hline Igkv1-135 & 0.6 & 33 & 61 & 0.0000 \\
\hline Slc1a6 & 2.1 & 82 & 39 & 0.0000 \\
\hline Mup5 & 123 & 4119 & 34 & 0.0000 \\
\hline Gpx3 & 295 & 7229 & 25 & 0.0000 \\
\hline Ighv1-67 & 1.6 & 36 & 22 & 0.0000 \\
\hline Saa3 & 2.2 & 47 & 22 & 0.0000 \\
\hline Tnfrsf11b & 6.3 & 116 & 18 & 0.0000 \\
\hline Cacnb3 & 24 & 325 & 13 & 0.0000 \\
\hline$N d n f$ & 89 & 1098 & 12 & 0.0000 \\
\hline$G m 4841$ & 3.8 & 44 & 12 & 0.0000 \\
\hline \multicolumn{5}{|c|}{ Downregulated in lateral ventricle $\mathrm{ChP}$} \\
\hline$N g f r$ & 444 & 83 & -5.3 & 0.0000 \\
\hline Nrn1 & 1924 & 496 & -3.9 & 0.0000 \\
\hline B3galt2 & 109 & 31 & -3.6 & 0.0007 \\
\hline Dazl & 207 & 60 & -3.4 & 0.0000 \\
\hline Itga10 & 184 & 54 & -3.4 & 0.0000 \\
\hline Slc26a7 & 1670 & 533 & -3.1 & 0.0000 \\
\hline Steap1 & 2224 & 735 & -3.0 & 0.0000 \\
\hline Defb11 & 473 & 169 & -2.8 & 0.0000 \\
\hline Entpd3 & 240 & 87 & -2.8 & 0.0001 \\
\hline Ccl9 & 2037 & 774 & -2.6 & 0.0000 \\
\hline \multicolumn{5}{|c|}{ Upregulated in 4 th ventricle $\mathrm{ChP}$} \\
\hline 9030619P08Rik & 0.00 & 28.6 & infinite & 0.0000 \\
\hline Tmigd1 & 0.00 & 33.1 & infinite & 0.0000 \\
\hline A730020M07Rik & 1.3 & 76 & 61 & 0.0000 \\
\hline Gpx3 & 181 & 10,780 & 59 & 0.0000 \\
\hline Cacnb3 & 18 & 778 & 43 & 0.0000 \\
\hline Mup5 & 26 & 1053 & 41 & 0.0000 \\
\hline Fmod * & 286 & 8688 & 30 & 0.0000 \\
\hline Slitrk6 & 4.7 & 125 & 27 & 0.0000 \\
\hline$N d n f$ & 84 & 2070 & 25 & 0.0000 \\
\hline Adcy 8 & 10 & 233 & 23 & 0.0000 \\
\hline \multicolumn{5}{|c|}{ Downregulated in 4 th ventricle $\mathrm{ChP}$} \\
\hline$N g f r$ & 684 & 159 & -4.3 & 0.0000 \\
\hline Steap1* & 1225 & 326 & -3.8 & 0.0000 \\
\hline Elfn1 & 104 & 28 & -3.7 & 0.0000 \\
\hline Gnmt & 122 & 33 & -3.7 & 0.0000 \\
\hline Gm22650 & 141 & 40 & -3.5 & 0.0000 \\
\hline Mir448 & 95 & 28 & -3.4 & 0.0002 \\
\hline $\operatorname{Igf} 2 o s$ & 89 & 26 & -3.4 & 0.0005 \\
\hline B3galt2 & 141 & 44 & -3.2 & 0.0000 \\
\hline Slc26a7 & 843 & 271 & -3.1 & 0.0000 \\
\hline Crhr2 & 504 & 164 & -3.1 & 0.0000 \\
\hline
\end{tabular}

The constitutive heterozygote $O t \times 2^{+/ G F P}$ adult mice showed significant expression changes in 528 genes of the $4 \mathrm{~V} \mathrm{ChP} \mathrm{(} p$-adj < 0.05), which is comparatively less than for conditional Otx2 knockdown in the $4 \mathrm{~V} \mathrm{ChP} \mathrm{(Figure} \mathrm{2A).} \mathrm{Given} \mathrm{that} \mathrm{fewer} \mathrm{genes} \mathrm{are}$ deregulated in this constitutive model, this suggests that compensatory mechanisms for countering reduced OTX2 levels were activated during development. The changes in gene expression were relatively balanced between upregulation ( 273 genes) and downregulation (255 genes), and ontology analysis revealed shared terms, including glycoprotein, signal, membrane-related, and secreted proteins (Figure 2B). The upregulated genes are also enriched for cell adhesion and alternative splicing, while downregulated genes are enriched 
for trafficking and transport. This suggests that brain-wide and life-long knockdown of Otx2 leads to altered ChP signaling, barrier functions, and brain homeostasis.
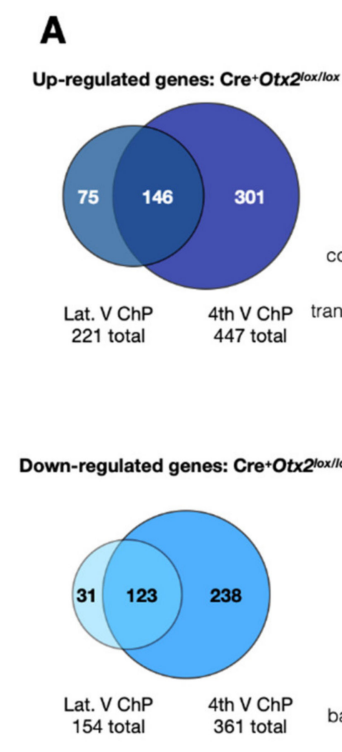
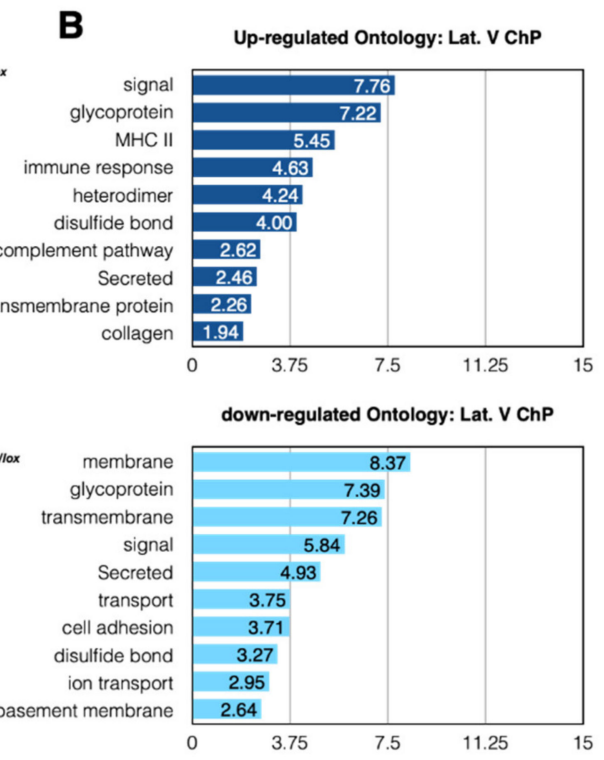
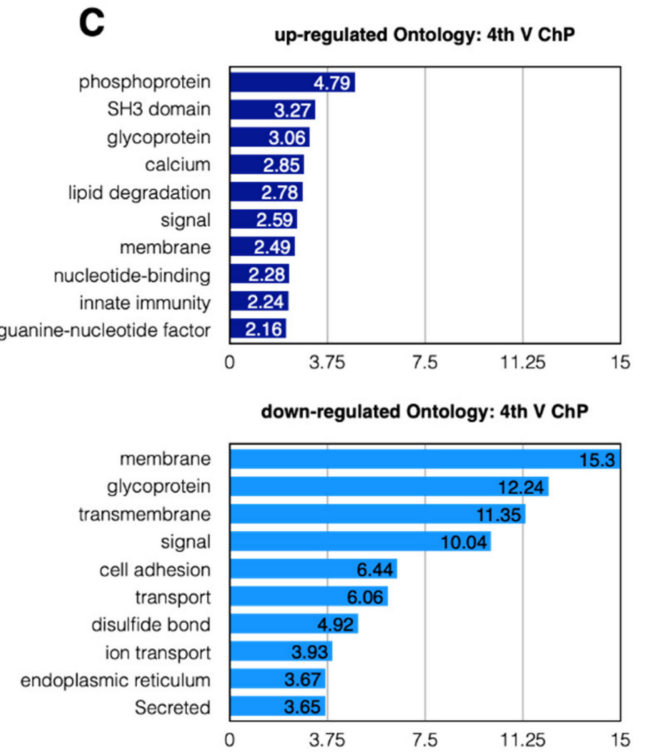

Figure 1. Changes in gene expression after conditional Otx2 knockdown in choroid plexus. (A) Venn diagrams of the number of up- or down-regulated genes $(p-a d j<0.05)$ from RNAseq analysis of ChP of Cre-Tat icv-injected Otx $2^{\text {lox/lox }}$ mice $\left(\mathrm{Cre}^{+} \mathrm{O} t x 2^{l o x / l o x}\right)$ compared to vehicle-injected mice. The diagrams compare the overlap between lateral ventricle (Lat. V ChP) and fourth ventricle (4th V ChP) differentially regulated genes; (B) Ontology analysis of differentially regulated genes in lateral ventricle $\mathrm{ChP}$ after conditional Otx2 knockdown; (C) Ontology analysis of differentially regulated genes in fourth ventricle $\mathrm{ChP}$ after conditional Otx2 knockdown.

A
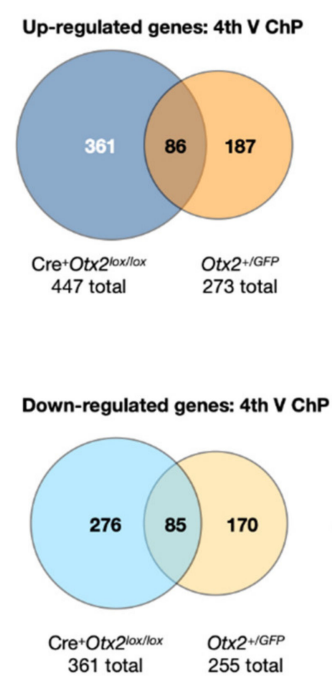

B
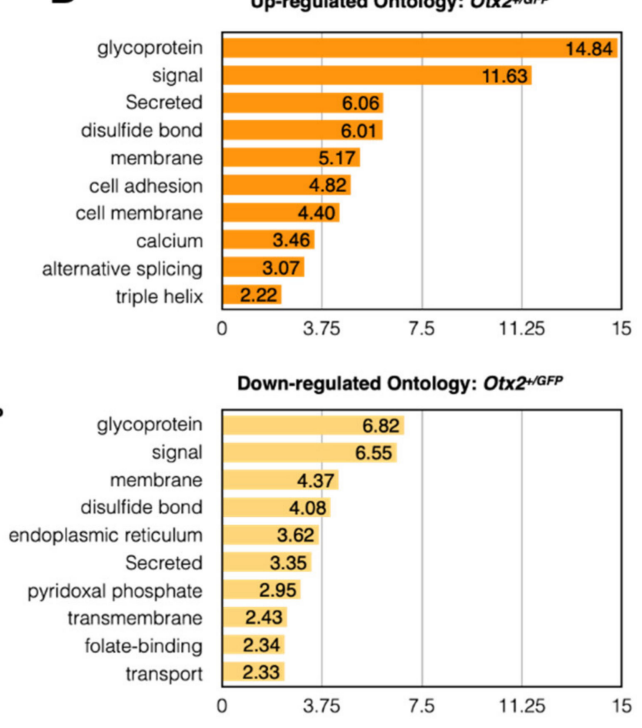

Figure 2. Gene expression in choroid plexus of $O t x 2^{+/ G F P}$ mice. (A) Venn diagrams of the number of up- or down-regulated genes $(p$-adj $<0.05)$ to compare overlap between fourth ventricle (4th $\mathrm{V} \mathrm{ChP})$ changes in $\mathrm{Otx} 2^{+/ G F P}$ mice and in Cre-Tat icv-injected Otx $2^{\text {lox/lox }}$ mice $\left(\mathrm{Cre}^{+} \mathrm{Otx} 2^{l o x / / o x}\right) ;(\mathbf{B})$ Ontology analysis of differentially regulated genes in $\mathrm{Otx} 2^{+/ G F P}$ mice.

We hypothesized that genes that were deregulated in both conditional and constitutive models could be either direct targets of OTX2 transcription regulation or targets of important OTX2-dependent pathways. Comparison of gene expression changes in $4 \mathrm{~V} \mathrm{ChP}$ of these two models revealed an overlap of more than 80 genes, in both the upregulated 
and downregulated repertoires (Figure 2A). This represented about half of the identified expression changes in Ot $x 2^{+/ G F P}$ mice, but less than a third of the changes in the conditional model. When genes from LV ChP conditional Otx2 knockdown are included in the analysis, we identified 42 genes that are globally upregulated and 34 genes that are globally downregulated (Table 3). To determine whether this list contains direct OTX2 transcription targets, we compared it with OTX2 chromatin immunoprecipitation experiments that were previously performed in mouse embryonic brain [9] or adult retina [14]. However, we found almost no overlap, with only Ttr being a common target. This suggests that the transcription-related activity of OTX2 is different in the adult choroid plexus and/or that these deregulated genes are downstream targets of OTX2-dependent pathways. It will be necessary to perform ChIPseq or CUT\&RUN analysis of adult choroid plexus, to distinguish between these possibilities. Taken together, our analysis identifies new potential functions for $O t \times 2$ in the adult brain. We found upregulation of immune factors, specifically in the conditional Otx2 loss-of-function model, and deregulation of genes involved in cellular adhesion, trafficking, signaling, and secretion, in both knockdown models, suggesting altered $\mathrm{ChP}$ function and disruption of the $\mathrm{ChP}$ barriers.

Table 3. Choroid plexus genes with significant expression changes in both Otx2 knockdown models, including lateral ventricle and fourth ventricle from $\mathrm{Cre}^{+} \mathrm{O} t \times 2^{\mathrm{lox} / \mathrm{lox}}$ mice and fourth ventricle from $O t x 2^{+/ G F P}$ mice. Genes with * are also deregulated upon embryonic Ot $x 2$ knockdown in the hindbrain choroid plexus [2].

\begin{tabular}{|c|c|c|c|}
\hline Up-Regulated & Function & Downregulated & Function \\
\hline Adora1 & Adenosine receptor & Aqp ${ }^{*}$ & Osmotic gradient \\
\hline Arrb1 & Receptor signaling & Atp $2 b 4$ & Ion transport \\
\hline Atp1a2* & Ion transport & B3galt2 & Glycosylation \\
\hline Cadm1 & Cell adhesion & Elfn1 & Signaling cascade \\
\hline Cd55 & Complement cascade & Entpd3 & \\
\hline Cfap 46 & & Fam132a & Glucose uptake \\
\hline Chn2 & Signaling cascade & $\operatorname{Igf2}$ & Growth factor \\
\hline Col11a1 & Collagen II fibrils & Ins2 & Glucose uptake \\
\hline Col1a2 & Collagen I fibrils & Kalrn & Signaling cascade \\
\hline Edn3 & Vasoconstriction & Klhl36 & Ubiquitination \\
\hline Eva1a & Cell death & Mapk9 & Cell signaling \\
\hline Fam $211 b$ & & Myo5b* & Cell trafficking \\
\hline Fgf1 & Growth factor & Myrip * & Cell trafficking \\
\hline Flrt1 & FGF signaling & Nav3 & Immune response \\
\hline Fmod * & Collagen I and II fibrils & Otx2 & Transcription factor \\
\hline$G d a$ & Metabolism & Pcnx * & \\
\hline Gpx3 & Oxidative stress & Pitpnm1 * & Cytoskeleton \\
\hline Hopx * & Chromatin structure & Pomgnt1 & Metabolism \\
\hline Layn & Hyaluronan receptor & $R c n 1$ & ER regulation \\
\hline Lrrc18 & Spermatogenesis & Scg5 & Cell secretion \\
\hline Mapk10 & Cell signaling & Sfrp1 & Wnt signaling \\
\hline Matn2 & Extracellular matrix & Slc29a4 & Cation transport \\
\hline $\operatorname{Megf11}$ * & Cell adhesion & Slc $2 a 12 *$ & Glucose transport \\
\hline Mlc1 & Osmotic gradient & Slc35f1 & Solute transport \\
\hline Mup5 & Pheromone activity & Slc41a2 & Magnesium transport \\
\hline$N d n f$ & Cell adhesion, growth & Stra6 & Retinol transport \\
\hline Ndrg3 & & $T b c 1 d 2$ & Cell adhesion \\
\hline Pi15 & Protease inhibitor & Tbcd & Cytoskeleton \\
\hline Plin4 & Adipocyte formation & Thumpd3 & \\
\hline Rufy4 & Autophagy & Tmem $255 b$ & \\
\hline Sel113 & & Tmprss11a & Cellular senescence \\
\hline Sema $5 a *$ & Cell adhesion & Tspan33* & Notch signaling \\
\hline
\end{tabular}


Table 3. Cont.

\begin{tabular}{cccc}
\hline Up-Regulated & Function & Downregulated & Function \\
\hline Shisal1 & Cilia function & Wtr & Retinol and $\mathrm{T}_{4}$ transport \\
Smrp1 & Neurofilament network & & \\
Sncg ${ }^{*}$ & & & \\
Sned $1^{*}$ & Signaling cascade & & \\
Sorcs 2 & Cell trafficking & & \\
Sorl1 & Extracellular matrix & & \\
Sulf2 & & & \\
Tm 4 sf1 & Cell filaments & & \\
Vim & & & \\
Vwa5b1 & & & \\
\hline
\end{tabular}

\subsection{Altered Expression of ChP Secreted Factors}

Given that our various ontology analyses often evoked secreted factors, we focused on ChP factors secreted in CSF and implicated in embryonic and/or adult neurogenesis (Table 4), which is one of the identified functions of adult ChP $[19,23,24]$. The factors implicated in embryonic neurogenesis include SHH, BMPs, and WNTs [25]. While Shh expression was not observed (mean reads $<1$ ) in either ChPs of the wildtype mice, which

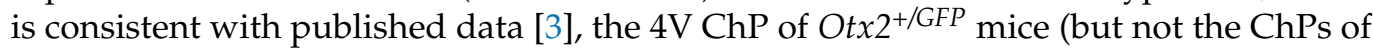
conditional Otx2 ChP knockdown mice) showed a significant increase in Shh expression. Between the various Bmp and Wnt family genes, only Bmp 7 and $W n t 2 b$ were differentially expressed in $\mathrm{Cre}^{+} \mathrm{Ot} x 2^{\text {lox/lox }}$ mice, as compared to $\mathrm{Veh}^{+} \mathrm{Ot} x 2^{\text {lox } / l o x}$ mice. Canonical Wnt signaling is perturbed in embryos with $O t x 24 \mathrm{~V} \mathrm{ChP} \mathrm{knockdown,} \mathrm{which} \mathrm{was} \mathrm{attributed} \mathrm{to}$ the dysregulation of Wnt modulators, including Rspo1, Sfrp2, Sostdc1, Tgm2, and Wnt4, and to the increased levels of WNT4 and TGM2 in the CSF of mutant mice [2]. While Rspo1, Sfrp2, and Wnt4 were very poorly expressed and unchanged in both the LV and $4 \mathrm{~V} \mathrm{ChP}$ of $\mathrm{Cre}^{+} \mathrm{Otx} 2^{\text {lox/lox }}$ adult mice, the expression of $S f r p 1$, Sostdc1, and Tgm2 were significantly changed in $4 \mathrm{~V} \mathrm{ChP} \mathrm{(Table} \mathrm{4),} \mathrm{suggesting} \mathrm{adult} \mathrm{OTX2} \mathrm{retains} \mathrm{some} \mathrm{embryonic} \mathrm{functions.}$ To further explore this hypothesis, we compared our RNA sequencing analysis of $4 \mathrm{~V}$ $\mathrm{ChP} \mathrm{Cre}{ }^{+} \mathrm{Ot} x 2^{l o x} / / 0 x$ to the previous microarray analysis of embryonic Otx 2 knockdown, specifically in the hindbrain ChP, performed by Götz and colleagues [2]. They found 340 significantly (FDR $<10 \%,>2$-fold change) expressed genes, with 135 genes upregulated and 225 genes downregulated. Compared to our adult knockdown, there was less than a $20 \%$ overlap with upregulated genes ( 24 of 135 genes) and an almost $30 \%$ overlap with downregulated genes (62 of 225 genes). Some of these genes are found among the top ten dysregulated $4 \mathrm{~V}$ genes (Table 2) and the globally altered genes (Table 3), and they have functions related to cell adhesion, trafficking, and secretion. Given that Otx2 knockdown experiments in late embryonic development showed that OTX2 is necessary for $4 \mathrm{~V}$, but not LV, ChP maintenance [2], our results suggest that adult Otx2 expression could retain this maintenance function in $4 \mathrm{~V} \mathrm{ChP.}$

We have previously shown that OTX2 that is secreted into the CSF from the ChP, can regulate adult neurogenesis non-cell autonomously, by transferring into the astrocytes in the SVZ and RMS, thereby affecting neuroblast migration [19]. This study also showed that ChP Otx2 knockdown in $\mathrm{Cre}^{+} \mathrm{Ot} x 2^{l o x / l o x}$ adult mice, which will impact both cell- and noncell-autonomous activity, also led to significantly reduced SVZ neurogenesis, suggesting that OTX2 may regulate secreted factors that are implicated in adult neurogenesis, through cell-autonomous effects in the ChP. IGF2 and SLIT1/2 regulate both embryonic and adult neurogenesis [24,26-28]. While Slit1 is not expressed and Slit3 is only weakly expressed in adult ChP, Slit2 is highly expressed, but shows no significant change in expression in the $\mathrm{ChP}$, with reduced Otx2. Admittedly, there is a trend towards increased Slit2 expression and we cannot exclude the potential for biological relevance. Igf2 was significantly downregulated, more than 2-fold, in all the ChPs, upon Otx2 knockdown. However, there was a concomitant downregulation in Igfbp2, which can inhibit IGF2, suggesting that the level 
of IGF2 activity could be maintained through the compensatory reduction in inhibiting factors. Other factors influencing adult neurogenesis include amphiregulin (AREG) [29], FGF2 [30-32], and TGF- $\alpha$ [33], yet we found no significant change in their expression (and no detectible expression of $\mathrm{Areg}$ ). Finally, other factors show more change in gene expression after acute $\operatorname{Ot} x 2$ knockdown compared to constitutive knockdown. TGF- $\beta$ negatively regulates adult neurogenesis [34], and Tgf- $\beta 2$ is downregulated in both the ChPs of $\mathrm{Cre}^{+} \mathrm{Otx} 2^{\text {lox/lox }}$ mice (Table 4). Taken together, these minimal or compensatory changes in specific secreted signaling factors suggest that $\mathrm{Otx} 2$ expression in the $\mathrm{ChP}$ could have only a minor cell-autonomous role in regulating adult neurogenesis. This hypothesis is consistent with similar levels of decrease in adult neurogenesis, observed with both this $\mathrm{ChP}$ Otx2 knockdown model and the non-cell-autonomous-only OTX2 knockdown mouse model [19].

Table 4. Expression of secreted factors in Otx2 knockdown experiments.

\begin{tabular}{|c|c|c|c|c|c|}
\hline Gene & Choroid Plexus & $\begin{array}{c}\text { Mean Reads, Control } \\
\text { (Either Veh or Wildtype) }\end{array}$ & $\begin{array}{c}\text { Mean Reads, } \\
\text { Knockdown (Either } \\
\text { Cre-Tat or } O t x 2^{+/ G F P} \text { ) }\end{array}$ & Fold Change & $p$-adj \\
\hline \multirow[t]{3}{*}{$B m p 7$} & Otx $2^{l o x / l o x} \mathrm{LV}$ & 5125 & 7090 & 1.4 & 0.1845 \\
\hline & Ot $x 2^{l o x / l o x} 4 \mathrm{~V}$ & 2547 & 4036 & 1.6 & 0.0014 \\
\hline & $O t x 2^{+/ G F P} 4 \mathrm{~V}$ & 2215 & 2261 & 1.0 & 1 \\
\hline \multirow[t]{3}{*}{ Wnt2b } & Otx $2^{l o x / l o x} \mathrm{LV}$ & 10 & 66 & 6.6 & 0.0002 \\
\hline & $O t x 2^{l o x / l o x} 4 \mathrm{~V}$ & 12 & 66 & 5.4 & 0.0001 \\
\hline & $O t x 2^{+/ G F P} 4 \mathrm{~V}$ & 29 & 35 & 1.2 & 1 \\
\hline \multirow[t]{3}{*}{$\operatorname{Tgm} 2$} & Otx $2^{l o x / l o x} \mathrm{LV}$ & 276 & 422 & 1.5 & 0.2496 \\
\hline & $O t x 2^{l o x / l o x} 4 \mathrm{~V}$ & 138 & 265 & 1.9 & 0.0040 \\
\hline & $O t x 2^{+/ G F P} 4 \mathrm{~V}$ & 388 & 404 & 1.0 & 1 \\
\hline \multirow[t]{3}{*}{ Sfrp1 } & Otx $2^{l o x / l o x} \mathrm{LV}$ & 8536 & 4511 & 0.53 & 0.0000 \\
\hline & Otx $2^{l o x / l o x} 4 \mathrm{~V}$ & 5121 & 2726 & 0.53 & 0.0000 \\
\hline & $O t x 2^{+/ G F P} 4 \mathrm{~V}$ & 4087 & 2001 & 0.49 & 0.0392 \\
\hline \multirow[t]{3}{*}{ Sostdc1 } & Otx $2^{l o x / l o x} \mathrm{LV}$ & 8627 & 4429 & 0.51 & 0.0000 \\
\hline & Ot $x 2^{l o x / l o x} 4 \mathrm{~V}$ & 5412 & 2793 & 0.52 & 0.0076 \\
\hline & $O t x 2^{+/ G F P} 4 \mathrm{~V}$ & 8932 & 8458 & 1.1 & 1 \\
\hline \multirow[t]{3}{*}{ Shh } & Ot $x 2^{l o x / l o x} \mathrm{LV}$ & 0 & 1.4 & infinite & 1 \\
\hline & Ot $x 2^{l o x / l o x} 4 \mathrm{~V}$ & 0.7 & 4.6 & 6.6 & 1 \\
\hline & $O t x 2^{+/ G F P} 4 \mathrm{~V}$ & 0 & 64 & infinite & 0.0000 \\
\hline \multirow[t]{3}{*}{ Slit2 } & Ot $x 2^{l o x / l o x} \mathrm{LV}$ & 2302 & 2674 & 1.2 & 1 \\
\hline & Ot $x 2^{l o x / l o x} 4 \mathrm{~V}$ & 3471 & 4803 & 1.4 & 0.7159 \\
\hline & Ot $x 2^{+/ G F P} 4 \mathrm{~V}$ & 4323 & 6099 & 1.4 & 0.6487 \\
\hline \multirow[t]{3}{*}{$F g f 2$} & Otx $2^{l o x / l o x} \mathrm{LV}$ & 140 & 123 & 0.88 & 1 \\
\hline & Ot $x 2^{l o x / l o x} 4 \mathrm{~V}$ & 64 & 84 & 1.3 & 0.9878 \\
\hline & $O t \times 2^{+/ G F P} 4 \mathrm{~V}$ & 67 & 66 & 1.0 & 1 \\
\hline \multirow[t]{3}{*}{ Areg } & Otx $2^{l o x / l o x} \mathrm{LV}$ & 0 & 0.9 & infinite & 1 \\
\hline & Ot $x 2^{l o x / l o x} 4 \mathrm{~V}$ & NA & NA & NA & NA \\
\hline & $O t \times 2^{+/ G F P} 4 \mathrm{~V}$ & 0 & 0 & NA & NA \\
\hline \multirow[t]{3}{*}{$T g f-\alpha$} & Ot $x 2^{l o x / l o x} \mathrm{LV}$ & 2140 & 1425 & 0.67 & 0.0620 \\
\hline & Ot $x 2^{l o x / l o x} 4 \mathrm{~V}$ & 1357 & 999 & 0.74 & 0.1611 \\
\hline & $O t \times 2^{+/ G F P} 4 \mathrm{~V}$ & 1040 & 1673 & 1.6 & 0.2163 \\
\hline \multirow[t]{3}{*}{$T g f-\beta 2$} & Otx $2^{l o x / l o x} \mathrm{LV}$ & 9233 & 4747 & 0.51 & 0.0000 \\
\hline & Ot $x 2^{\text {lox/lox }} 4 \mathrm{~V}$ & 3755 & 2169 & 0.58 & 0.0000 \\
\hline & $O t \times 2^{+/ G F P} 4 \mathrm{~V}$ & 3324 & 2563 & 0.77 & 0.3602 \\
\hline \multirow[t]{3}{*}{$\operatorname{Igf2}$} & Ot $x 2^{l o x / l o x} \mathrm{LV}$ & 42,336 & 19,144 & 0.45 & 0.0008 \\
\hline & $O t \times 2^{l o x / l o x} 4 \mathrm{~V}$ & 18,717 & 8087 & 0.43 & 0.0000 \\
\hline & $O t \times 2^{+/ G F P} 4 \mathrm{~V}$ & 42,542 & 17,197 & 0.40 & 0.0000 \\
\hline \multirow{3}{*}{$I g f b p 2$} & Otx $2^{l o x / l o x} \mathrm{LV}$ & 30,195 & 20,992 & 0.70 & 0.3255 \\
\hline & $O t x 2^{10 x / l o x} 4 \mathrm{~V}$ & 28,166 & 13,235 & 0.47 & 0.0003 \\
\hline & $O t \times 2^{+/ G F P} 4 \mathrm{~V}$ & 47,529 & 21,660 & 0.46 & 0.0000 \\
\hline
\end{tabular}




\subsection{Altered Expression of Immune and Stress Factors}

Given the altered expression of homeostasis and stress response-related factors in both the ChPs of conditional Otx2 knockdown mice, we turned to the viral expression of shRNA-Otx2 in LV and 4V ChPs. Intracerebroventricular-injected AAV5 results in ChPspecific expression $[35,36]$, and provides a tool to acutely affect Otx2 expression in any mouse model. We validated this model by qPCR analysis, which showed a $69 \%$ decrease in (mRNA) Otx2 and a concomitant very large decrease in the expression of a known direct transcriptional target, transthyretin (Ttr) (Figure 3A). Comparing models, the decrease in (mRNA) Ttr in $\mathrm{Cre}^{+} \mathrm{Otx} 2^{l o x / l o x}$ mice was $45 \%$, while it was $87 \%$ in the shRNA-Ot $x 2$ mice, which suggests that viral knockdown provides a more robust effect. TTR, the most highly expressed protein in ChP (Table 1), is secreted into CSF and transports thyroxin and retinolbinding protein, and has a role in regulating cognition and memory, psychological health, and emotions (for a recent review, see [37]), suggesting that OTX2 levels can potentially impact similar brain functions. Furthermore, the downregulation of aquaporin 1 (Aqp1) (Table 3, Figure 3A) was also confirmed, with Aqp4 as a negative control, suggesting that OTX2 can also regulate CSF water homeostasis.

A
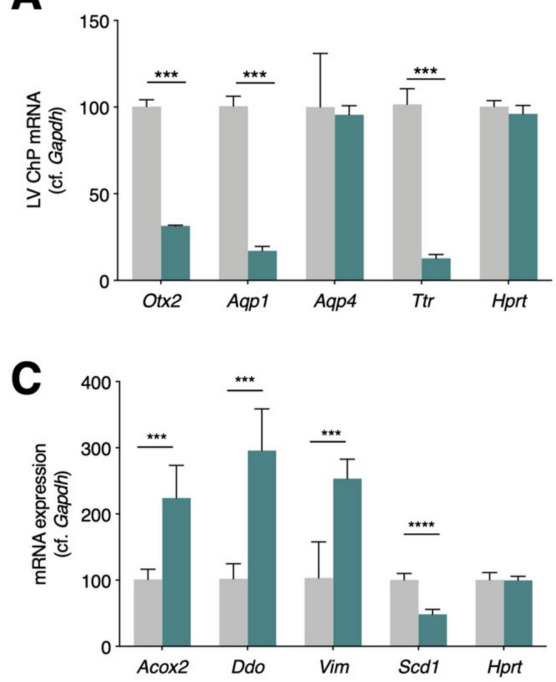

B
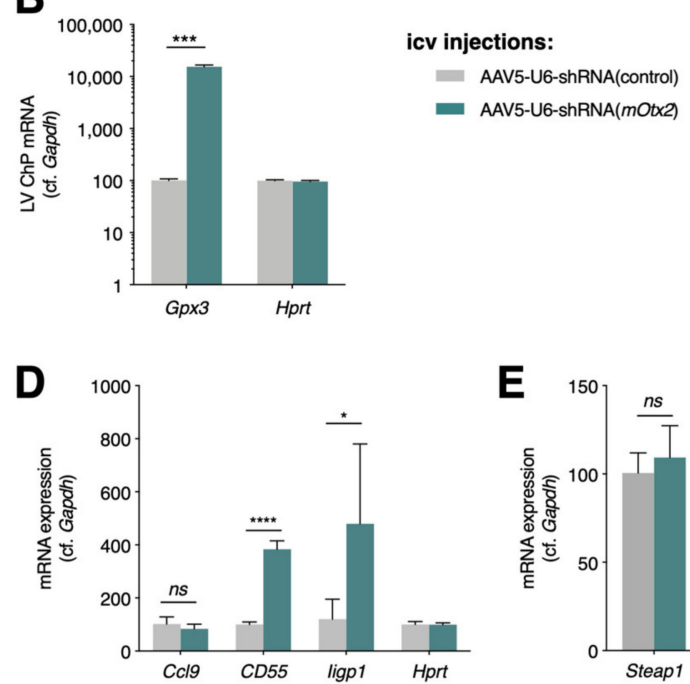

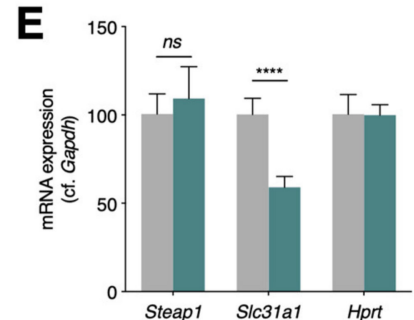

Figure 3. OTX2 regulates choroid plexus expression of oxidative stress, immune system, and metal transport genes. Quantitative PCR analysis of lateral ventricle (LV) ChP gene expression in wildtype mice after viral expression of shRNA against mouse (mRNA) Otx2 (shRNA-mOtx2) compared to control shRNA. (A) Analysis of control genes to validate shRNA-Otx2 activity; (B) Otx2 knockdown induces high expression of Gpx3; (C) Analysis of select genes involved in oxidative stress response; (D) Analysis of select genes involved in immune system response; (E) Analysis of select genes involved in metal ion transport (all values: mean $\pm \mathrm{SEM} ; n=5$; $t$-test; ${ }^{*} p<0.05$, ${ }^{* * *} p<0.001$, ${ }^{* * *} p<0.0001$ ).

In keeping with roles in brain homeostasis and surveillance, we also chose targets from ontology analysis (Figure 1), in functions related to oxidative stress, immune response, and metal ion transport. A surprising finding was the over 100-fold increase in glutathione peroxidase 3 (Gpx3), an extracellular enzyme that catalyzes the reduction in peroxidases and protects cells from oxidative damage, suggesting that a loss of OTX2 has a significant impact on cell physiology (Figure 3B). Other compensatory mechanisms against oxidative stress include decreased fatty acid oxidation $(S c d 1)$, increased peroxisome function (Acox2, $D d o$ ), for countering oxidative stress and inflammation [38], and changes in the structural cell response (Vim) [39] (Figure 3C). Concerning the immune response (Figure 3D), we tested a complement activation factor (CD55), an inflammatory response chemokine (Ccl9), and an innate immune response factor (Iigp1). The direction of change in the expression of all of these factors, upon acute viral Otx2 knockdown, was consistent with the constitutive and conditional mouse models. It remains unclear whether the loss of OTX2 provokes 
oxidative stress, and thus indirect activation of genes such as Gpx3, or whether OTX2 regulates the genes involved in reactive oxygen species signaling and/or stress response. Finally, given their role in brain homeostasis, we also quantified factors related to metal ion transport (Steap1 and Slc31a) (Figure 3E), which had altered expression in the conditional $\mathrm{Cre}^{+} \mathrm{Ot} x 2^{\text {lox/lox }}$ mice. Only Slc31a, which transports copper ion, had concomitant reduced expression upon $\mathrm{Ot} x 2 \mathrm{knockdown}$. These findings suggest that $\mathrm{ChP}$ function is greatly impacted by Otx2 expression level, opening the question of whether Otx2 overexpression in $\mathrm{ChP}$ would also deregulate homeostasis and illicit immune responses in a wildtype context or, on the contrary, rescue deficits in homeostasis in an aged or diseased animal.

\subsection{Otx2 Protein Interactions}

To further analyze OTX2 function in adult ChP, we performed several OTX2 coimmunoprecipitation (co-IP) experiments with mass spectrometry (MS) analysis, to identify potential protein partners. We previously discovered that OTX2 protein is secreted by the ChP into CSF, and accumulates non-cell autonomously in SVZ and RMS astrocytes [19] and VCx parvalbumin cells [5,40]. The identification of alternate protein partners in cellautonomous and non-cell-autonomous contexts would suggest that OTX2 takes on specific roles after transferring between cells. To test this hypothesis, and to reinforce $\mathrm{ChP}$ analysis, we also performed OTX2 co-IP on lysates from adult mouse SVZ, RMS, and VCx.

We used three criteria to obtain a list of potential OTX2 protein interactions in the four brain structures (Table 5), as follows: (i) unique proteins with three or more peptides identified exclusively in OTX2 compared to IgG co-IP samples (unique protein, $\geq 3$ peptides); (ii) proteins identified with three or more peptides in OTX2 co-IP samples and having a relative peptide difference greater than $50 \%$ compared to IgG co-IP (selected protein, $\geq 50 \%$ rel. $\Delta$ ); and (iii) all small proteins ( $\leq 25 \mathrm{kDa}$ ) exclusive to OTX2 co-IP samples, regardless of peptide number (unique small protein, $\leq 25 \mathrm{kDa}$ ), given that they have fewer identifiable MS peptides. These lists were used for comparison between structures and for ontology analysis. We generated a list of 60 high-confidence protein partners of OTX2 in $\mathrm{ChP}$ that were common to all three $\mathrm{ChP}$ samples (Table 6). These proteins cover several functions, including cell adhesion, cell trafficking, cell signaling, metabolism, RNA binding, RNA processing, transcription, chromatin structure, and DNA repair. Interestingly, more than $10 \%$ (eight proteins) belong to the "tier 1" proteins identified in stress granules [41], which are involved in translational control and post-transcriptional regulation. Although this functional class was not identified by KEGG pathway analysis (see below), this is likely due to the absence of annotation, given the only recent emergence of updated comprehensive inventories of stress granule proteins. Thus, we can only hypothesize that OTX2 interacts with these granules, although this putative function is given weight by the presence of the PAX1 homeoprotein among the "tier 1" proteins, by the in vivo interaction between the EMX2 homeoprotein with the translation initiation factor eIF4E [42], and by the involvement of the PROX1 homeoprotein in liquid-liquid phase separation [43], which also underlies stress granule assembly [41]. Also of note are the putative partners MECP2 and MOV10, given that OTX2 has been shown to regulate MECP2 foci in the postnatal mouse visual and auditory cortex [16], and that the EN1 homeoprotein is involved in LINE-1 regulation [44].

Table 5. Summary of protein lists and criteria for identification of putative OTX2 protein partners.

\begin{tabular}{ccccc}
\hline List Name & Choroid Plexus & SVZ & RMS & Visual Cortex \\
\hline Total proteins OTX2 & 4814 & 1138 & 2425 & 2644 \\
Total proteins IgG & 3602 & 1776 & 2274 & 2667 \\
Unique proteins OTX2 $(\geq 3$ peptides) & 392 & 17 & 40 & 29 \\
Unique proteins IgG $(\geq 3$ peptides) & 59 & 139 & 22 & 25 \\
Selected proteins OTX2 $(\geq 50 \%$ rel. $\Delta)$ & 653 & 6 & 75 & 37 \\
Unique small proteins Otx2 $(\leq 25 \mathrm{kDa})$ & 182 & 31 & 68 & 48 \\
Total OTX2 partners & 1195 of 4814 & 52 of 1138 & 180 of 2425 & 109 of 2644 \\
\hline
\end{tabular}


Table 6. High-confidence OTX2 putative protein partners in choroid plexus identified by MS analysis. Proteins indicated in bold are unique for OTX2 co-IP, proteins with * are "tier 1" stress granule proteins.

\begin{tabular}{|c|c|c|c|}
\hline Protein & Function & Protein & Function \\
\hline $\mathrm{ABCF} 1$ * & Translation & MAP4 & Cytoskeleton \\
\hline ACOT11 & Lipid metabolism & MCMЗАP & RNA export \\
\hline AGO1 * & RNA silencing & MECP2 & Transcription, epigenetics \\
\hline APC & Cell adhesion & MLYCD & Metabolism \\
\hline ARHGEF6 & Trafficking & MOV10 * & RNA and LINE-1 silencing \\
\hline ARHGEF7 & $\begin{array}{l}\text { Trafficking, cell } \\
\text { adhesion }\end{array}$ & MSI2 * & Translation \\
\hline ARVCF & Cell adhesion & MYCBP2 & Transcription \\
\hline $\mathrm{CDH} 2$ & Cell adhesion & NFATC2 & Signaling \\
\hline $\mathrm{CDH} 3$ & Cell adhesion & PIKFYVE & Trafficking \\
\hline CHD4 & Cell adhesion & PITPNM2 & Trafficking \\
\hline CTNNA1 & Cell adhesion & POLDIP3 & Translation \\
\hline CTNNA2 & Cell adhesion & PRRC2A * & RNA splicing, stress granule \\
\hline CTNNB1 & Cell adhesion & RBM39 & RNA splicing \\
\hline DDX41 & RNA splicing & RHOT1 & Mitochondrial trafficking \\
\hline EDC4 * & RNA processing & RPL19 & \\
\hline EPB41L5 & Cell adhesion & RPL21 & Translation \\
\hline ERBIN & Signaling & RPL22 & \\
\hline FIG4 & Trafficking & RPL29 & Translation \\
\hline FMNL3 & Cytoskeleton & RPL35 & Translation \\
\hline GIT1 & $\begin{array}{l}\text { Trafficking, cell } \\
\text { adhesion }\end{array}$ & RPL36A & \\
\hline GIT2 & Trafficking & SRRM2 & RNA splicing \\
\hline GJA1 & Gap junction & STRAP * & Stress response \\
\hline GPAM & Metabolism & TJP2 & Cell adhesion \\
\hline GTPBP1 & RNA processing & TMPO & Nuclear membrane \\
\hline HNRPLL * & RNA splicing & TNS2 & Signaling \\
\hline ILF2 & Transcription & TRPV4 & Osmotic sensitivity \\
\hline KIFAP3 & $\begin{array}{l}\text { Chromosome } \\
\text { structure }\end{array}$ & VAC14 & Trafficking \\
\hline LBR & Metabolism & VRK3 & Signaling \\
\hline LIG3 & DNA repair & WDR70 & \\
\hline MAP1A & Cytoskeleton & ZFR & RNA export \\
\hline
\end{tabular}

Few OTX2 partners have been biochemically and functionally validated. One key partner during embryogenesis is MEIS2, which is a co-activator for mesencephalon specification [45]. Meis 2 is expressed in ChP at low levels (170 mean reads in 4V ChP; 31 mean reads in LV ChP), as compared to OTX2 (5954 mean reads in $4 \mathrm{~V} \mathrm{ChP} \mathrm{and} 6829$ mean reads in LV ChP), and appears not to be a major partner of OTX2 in ChP. TLE4 is another identified protein partner of OTX2 during development, and allows repression of mesencephalon fate [46]. Despite its expression in ChP (798 mean reads in $4 \mathrm{~V} \mathrm{ChP} \mathrm{and} 689$ mean reads in LV ChP), TLE4 was not identified in our OTX2 co-IP, although this could be due to TLE4 being under the limit of detection or having peptides that are too hydrophobic or hydrophilic for MS detection. The potential absence of TLE4 suggests that OTX2 protein interactions depend strongly on the cell type and developmental context.

To identify novel OTX2 protein partners that are ubiquitous throughout the brain, we compared the lists from the four brain structures, as follows: ChP (pooled LV and 4V), SVZ, RMS, and VCx. Few high-confidence proteins (selected protein $\geq 50 \%$ rel. $\Delta$ ), 14 in total, were common to the three non-cell-autonomous structures (Table 7). Of these 14 common proteins, 5 were also identified in the ChP. Interestingly, these top-ranked proteins include FIG4, VAC14, and PIKFYVE, which play a role in phosphatidylinositol $(3,5)$ bisphosphate [PI $(3,5) \mathrm{P} 2]$ regulation, in multivesicular body (MVB) biogenesis, and in endosome autophagy and trafficking [47], suggesting that OTX2 plays a role in vesicle transport or is carried via MVBs. Given that MVBs can give rise to extracellular vesicles, interaction with OTX2 may reinforce its role in regulating the pathways of extracellular protein expression that are identified in our RNA sequencing analysis. 
Table 7. Peptide number comparisons of OTX2 putative protein partners common to non-cell-autonomous structures. Cell-autonomous partners are indicated in bold.

\begin{tabular}{|c|c|c|c|c|c|c|c|c|c|}
\hline \multirow[t]{2}{*}{ Protein } & \multirow[t]{2}{*}{ Function } & \multicolumn{2}{|c|}{ SVZ } & \multicolumn{2}{|c|}{ RMS } & \multicolumn{2}{|c|}{ VCx } & \multicolumn{2}{|c|}{ ChP } \\
\hline & & $\begin{array}{l}\text { Otx2 } \\
\text { co-IP }\end{array}$ & $\underset{\text { co-IP }}{\text { IgG }}$ & $\begin{array}{l}\text { Otx2 } \\
\text { co-IP }\end{array}$ & $\underset{\text { co-IP }}{\text { IgG }}$ & $\begin{array}{l}\text { Otx2 } \\
\text { co-IP }\end{array}$ & $\begin{array}{c}\text { IgG } \\
\text { co-IP }\end{array}$ & $\begin{array}{l}\text { Otx2 } \\
\text { co-IP }\end{array}$ & $\underset{\text { co-IP }}{\text { IgG }}$ \\
\hline ACIN1 & mRNA splicing & 3 & 0 & 11 & 1 & 16 & 4 & & \\
\hline ACOT11 & Lipid metabolism & 4 & 0 & 5 & 0 & 8 & 1 & 34 & 7 \\
\hline ARCN1 & Protein transport & 3 & 1 & 7 & 2 & 4 & 1 & & \\
\hline DDX46 & mRNA splicing & 30 & 0 & 45 & 1 & 34 & 3 & & \\
\hline EIF4A3 & mRNA translation & 4 & 0 & 10 & 2 & 11 & 5 & & \\
\hline FIG4 & $\mathrm{PI}(3,5) \mathrm{P} 2$ regulation, $\mathrm{MVB}$ & 20 & 0 & 26 & 0 & 27 & 0 & 43 & 0 \\
\hline KCND3 & Potassium channel & 6 & 0 & 5 & 0 & 7 & 0 & 6 & $\mathbf{0}$ \\
\hline PIKFYVE & $\mathrm{PI}(3,5) \mathrm{P} 2$ regulation, $\mathrm{MVB}$ & 36 & 0 & 42 & 0 & 59 & 0 & 122 & 1 \\
\hline RBM 25 & mRNA splicing & 5 & 0 & 11 & 1 & 12 & 3 & & \\
\hline SF3A1 & mRNA splicing & 3 & 0 & 11 & 3 & 13 & 6 & & \\
\hline SF3B1 & mRNA splicing & 3 & 0 & 22 & 0 & 25 & 9 & & \\
\hline SNRNP200 & mRNA splicing & 5 & 0 & 14 & 1 & 31 & 4 & & \\
\hline THOC2 & mRNA export & 3 & 0 & 5 & 0 & 3 & 0 & & \\
\hline VAC14 & $\mathrm{PI}(3,5) \mathrm{P} 2$ regulation, $\mathrm{MVB}$ & 39 & 2 & 49 & 3 & 56 & 0 & 75 & 0 \\
\hline
\end{tabular}

To identify potential differences between cell-autonomous and non-cell-autonomous partners, we performed KEGG pathway analysis on OTX2 protein partners, for all structures individually (Table 8). No dramatic differences were found between the structures, suggesting conserved roles of OTX2 in cell-autonomous and non-cell-autonomous OTX2 target structures. Common to nearly all structures are metabolic pathways, RNA transport, oxidative phosphorylation, RNA processing, and spliceosome. Pathways that are specific to the $\mathrm{ChP}$ pertain to the maintenance of tight junctions, protein processing, and actin cytoskeleton regulation. Downregulation of the cell adhesion class was also identified in the RNAseq analysis of conditional $\mathrm{Cre}^{+} \mathrm{Ot} x 2$-lox mice (Figure 1), suggesting a direct involvement of OTX2 both in gene regulation and cellular functions for cell-autonomous $\mathrm{ChP}$ maintenance. Of the 14 proteins in common between VCx, SVZ, and RMS, eight of them are involved in RNA processing, suggesting a novel function for OTX2. Although the spliceosome pathway was also enriched in $\mathrm{ChP}$, these proteins stand out for their involvement in the U5 snRNP complex, exon junction complex, or mRNA export complex, whereas the spliceosome proteins identified in the $\mathrm{ChP}$ are either splicing co-factors, part of the SMN complex, or part of the U2 snRNP complex. Interestingly, OTX2 has been shown to bind the initiation factor eIF4e in GST pull-down experiments [42], while other homeoproteins have been shown to bind translation machinery $[6,42,48]$ that is implicated in RNA export, transport, and translation. Taking the high-confidence partners together with KEGG pathway analysis, cell-autonomous OTX2 is likely implicated in the regulation of genomic landscape, the regulation and processing of RNA, the trafficking of signals, and the maintenance of cellular adhesion, while non-cell-autonomous OTX2 is more implicated in the processing of RNA.

\subsection{Splice Variant Analysis}

Given the high confidence of OTX2 interaction with spliceosome pathway proteins, we extended the analysis of our transcriptomic data of $\mathrm{LV} \mathrm{ChP}$ from $\mathrm{Cre}^{+} \mathrm{Otx} 2^{\text {lox } / l o x}$ mice to measure changes in splice variants. The isoform usage was found to be significantly changed in the coding transcripts for only four genes (Mcrs, Ldlr, Tspan12, and Daxx), and generally for only two isoforms among the splice variants (Figure $4 \mathrm{~A}, \mathrm{~B})$. These genes showed no change in overall expression upon Otx2 knockdown (Figure 4C). Through acute $O t \times 2$ knockdown by the viral expression of shRNA-Otx2, we confirmed a significant increase in the expression of only the Mcrs-209 and Daxx-204 isoforms, as other isoforms either did not change significantly or changed in the opposite direction (Figure 4D). Interestingly, MCRS and DAXX interact within a protein complex with various nuclear functions, including transcription regulation, chromatin remodeling, and DNA repair. Further research is needed to determine the functional consequences of these changes in the distribution of transcript isoforms. 
Table 8. List of KEGG pathways associated with putative cell- and non-cell-autonomous OTX2 protein partners.

\begin{tabular}{|c|c|c|}
\hline KEGG Pathway & Size & $p$-adj \\
\hline \multicolumn{3}{|l|}{ Choroid plexus (1326 proteins) } \\
\hline Tight junction & 27 of 137 & 0.0000 \\
\hline Metabolic pathways & 77 of 1184 & 0.0000 \\
\hline Protein processing in ER & 26 of 169 & 0.0000 \\
\hline RNA transport & 24 of 168 & 0.0000 \\
\hline Ribosome biogenesis & 18 or 86 & 0.0000 \\
\hline Regulation of actin cytoskeleton & 27 of 216 & 0.0000 \\
\hline Ribosome & 19 of 119 & 0.0000 \\
\hline Spliceosome & 20 of 138 & 0.0000 \\
\hline Oxidative phosphorylation & 20 of 147 & 0.0000 \\
\hline Axon guidance & 18 of 131 & 0.0000 \\
\hline \multicolumn{3}{|l|}{ SVZ (79 proteins) } \\
\hline Ribosome & 15 of 119 & 0.0000 \\
\hline Spliceosome & 15 of 138 & 0.0000 \\
\hline RNA transport & 4 of 168 & 0.0004 \\
\hline mRNA surveillance & 2 of 93 & 0.0219 \\
\hline Neurotrophin signaling & 2 of 131 & 0.0297 \\
\hline \multicolumn{3}{|l|}{ RMS (219 proteins) } \\
\hline Spliceosome & 28 of 138 & 0.0000 \\
\hline Oxidative phosphorylation & 11 of 147 & 0.0000 \\
\hline Metabolic pathways & 24 of 1184 & 0.0000 \\
\hline Alzheimer disease & 10 of 188 & 0.0000 \\
\hline mRNA surveillance & 8 of 93 & 0.0000 \\
\hline \multicolumn{3}{|l|}{ Visual cortex (192 proteins) } \\
\hline Spliceosome & 17 of 138 & 0.0000 \\
\hline RNA transport & 7 of 168 & 0.0000 \\
\hline Metabolic pathways & 14 of 1184 & 0.0005 \\
\hline Insulin signaling & 5 of 137 & 0.0007 \\
\hline Oxidative phosphorylation & 5 of 147 & 0.0007 \\
\hline
\end{tabular}

A

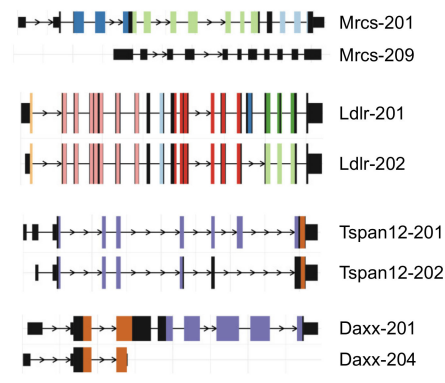

B

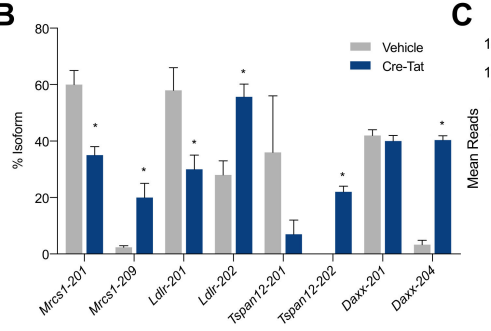

C
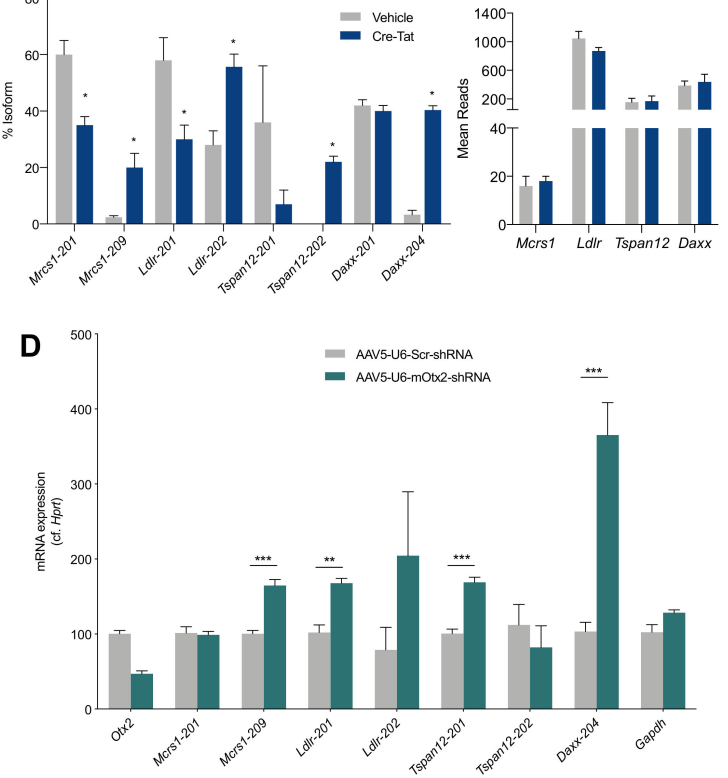

Figure 4. Analysis of splice variations induced by Otx2 knockdown in choroid plexus. (A) Selected isoforms of genes of interest. Locus length is in arbitrary units. Colors represent different protein domains 
within a given gene; (B) Isoform usage, shown as \% of total isoforms, in lateral ventricle (LV) ChP from vehicle and Cre-Tat icv-injected Ot $x 2^{\text {lox/lox }}$ mice; (C) Mean reads from transcriptomic analysis of LV ChP from vehicle and Cre-Tat icv-injected Ot $x 2^{\text {lox/lox }}$ mice; (D) Quantitative PCR analysis of LV ChP isoform expression in wildtype mice after viral expression of shRNA against mouse (mRNA) Otx2 (shRNA-Otx2) (all values: mean \pm SEM; $n=5 ;$-test; ${ }^{*} p<0.05,{ }^{* *} p<0.01,{ }^{* * *} p<0.001$ ).

Homeoproteins have been postulated to regulate transcript splicing. The PAX6 homeoprotein has been shown to modulate splicing machinery, such that changes in $\operatorname{Pax} 6$ expression alter the population of tenascin-C splice variants without changing the total tenascin-C expression [49], while the CDX2 homeoprotein interacts with splicing machinery [50]. Regarding OTX2, its protein interactome in the adult retina revealed putative RNA processing partners, such as SFPQ and U2AF [15], while in the ChP and non-cellautonomous structures, we found the potential partners ACIN1, DDX41, DDX46, HNRPLL, and PRRC2A, RBM25, RBM39, SF3A1, SF3B1, SNRNP200, and SRRM2 (Tables 6 and 7). It remains to be determined whether OTX2 controls $\mathrm{ChP}$ splicing activity through direct interaction with splicing factors and/or by regulating their expression.

\section{Materials and Methods}

\subsection{Animal Ethics Statement}

All animal procedures, including housing, were carried out in accordance with the recommendations of the European Economic Community (2010/63/UE) and the French National Committee (2013/118). For surgical procedures, animals were anesthetized with xylazine (Rompun 2\%, $5 \mathrm{mg} / \mathrm{kg}$ ) and ketamine (Imalgene 500, $80 \mathrm{mg} / \mathrm{kg}$ ). For biochemical analysis, mice either underwent transcardial perfusion or were sacrificed by cervical elongation.

\subsection{Animals and Stereotaxic Surgery}

Ot $x 2^{l o x / l o x}$ mice were kindly donated by T. Lamonerie [51] and Ot $x 2^{+/ G F P}$ mice by A. Simeone [52]. Three-month-old Ot $x 2^{l o x / l o x}$ mice were injected with Cre-Tat or vehicle as described in [19] and housed for 15 days after surgery. The following serotype 5 adenoassociated viruses (AAV5) were purchased from Vector Biolabs (Malvern, PA, USA): AAV5CMV-EGFP-U6-shRNA (control); and AAV5-CMV-EGFP-U6-shRNA (mOtx2). High-titer AAV5 ( $10^{13} \mathrm{GC} / \mathrm{mL}$ ) were injected ( $2 \mu \mathrm{L}$ per mouse) bilaterally into the LV (coordinates from bregma: $x,-0.58 \mathrm{~mm} ; \mathrm{y}, \pm 1.28 \mathrm{~mm} ; \mathrm{z},-2 \mathrm{~mm}$ ) with a $10 \mu \mathrm{L}$ Hamilton syringe $(0.2 \mu \mathrm{L} / \mathrm{min})$. Virus-injected mice were housed for 3 weeks after surgery. Animals were an equal mix of males and females. The Ot $x 2^{+/ G F P}$ mice, littermates, and the injected Ot $x 2^{\text {lox } / l o x}$ mice underwent transcardial perfusion with $20 \mathrm{~mL}$ saline phosphate buffer, and ChPs were dissected and processed for biochemical analysis. Virus-injected mice were sacrificed by cervical elongation for ChP extraction.

\subsection{Quantitative PCR Analysis}

Total RNA from LV and 4V ChPs was extracted by using the RNeasy lipid tissue mini kit (Qiagen, Courtaboeuf, France) with DNA removal. Total RNA (10 to $20 \mathrm{ng}$ ) was retrotranscribed by using the QuantiTect reverse transcription kit (Qiagen, Courtaboeuf, France). Quantitative PCR (qPCR) analyses of cDNA (diluted at 1/10) were performed in triplicate with a LightCycler 480 II (Roche, Meylan, France) using the SYBR Green I master mix (Roche, Meylan, France). Gene-to-Hprt or gene-to-Gapdh ratios were determined by the $2^{-\Delta \Delta \mathrm{Ct}}$ method. For Otx2 expression analysis, expression was compared to mean expression of vehicle-injected mice of the same experiment.

\subsection{RNA Sequencing Analysis}

For analysis of conditional knockdown mice, the RNA was extracted separately from LV and 4V ChPs of Cre-Tat and vehicle-injected mice. A small sample of each ChP was tested by qPCR to ensure Cre-Tat samples had less than 50\% Otx2 expression on 
average compared to control mice. Duplicate samples were prepared by pooling ChP lysates from $2 \times 5$ Cre-Tat-injected mice and from $2 \times 4$ vehicle-injected mice. For analysis of constitutive knockout mice, the RNA was extracted from pooled $4 \mathrm{~V}$ ChPs of four 3 -month-old $O t \times 2^{+/ G F P}$ and five wildtype littermates, with duplicate samples $(n=2)$ of each genotype. PolyA + mRNA purification, mRNA sequencing with technical replicates, and data normalization and quantification was performed by the Genomic Paris Center (IBENS, Paris, France) using Illumina HiSeq 1500 (Illumina, Evry, France).

\subsection{Isoform Analysis}

Raw reads were processed with FASTP [53] using standard parameters, and then pseudo-aligned on mm10 GENCODE transcriptome using salmon [54]. The quantified transcriptome was then imported in $\mathrm{R}$ using the IsoformSwitchAnalyzeR package $[55,56]$ with dIFcutoff $=0.15$. Isoform switch test was performed using DEXseq $[57,58]$ in IsoformSwitchAnalyzeR. Gene coding potential, secondary structures, signal peptides, and protein domains were analyzed with CPAT [59], Net-Surf2 [60], SignalP [61], and Pfam [62], respectively.

\subsection{Protein Co-Immunoprecipitation}

For each $\mathrm{ChP}$ co-IP experiment, $\mathrm{ChP}$ from $\mathrm{LV}$ and $4 \mathrm{~V}$ were pooled from four 3month-old mice and were lysed with $1 \mathrm{~mL}$ lysis buffer (100 mM Tris pH 7.5, $1 \mathrm{mM}$ EDTA, $100 \mathrm{mM} \mathrm{NaCl}, 1 \% \mathrm{NP} 40,1 \mathrm{mM} \mathrm{MgCl}$, $1 \mathrm{X}$ protease/phosphatase inhibitor (Roche, Meylan, France)) containing $1 \mu \mathrm{L}$ of benzonase (Roche, Meylan, France). $\mathrm{ChP}$ were dissociated using $26 \mathrm{G}$ syringe and incubated $30 \mathrm{~min}$ on ice. Tubes were centrifuged at $21,000 \times \mathrm{g}$ for $10 \mathrm{~min}$ and supernatant was recovered and divided in two. Each half was incubated with $44 \mu \mathrm{g}$ of either anti-OTX2 (ab21990, Abcam, Paris, France) or anti-IgG (ab27478, Abcam, Paris, France) antibodies coupled to magnetic beads $(10 \mathrm{mg} / \mathrm{mL}$ with $9.5 \mu \mathrm{g}$ of antibody per mg of beads, Dynabeads antibody coupling kit, Invitrogen, Vilnius, Lithuania) in lysis buffer at $4{ }^{\circ} \mathrm{C}$ on rotating wheel overnight. Using magnetic separation, beads were washed 5 times in $1 \mathrm{~mL}$ of cold lysis buffer. Pelleted beads were eluted in $20 \mu \mathrm{L}$ of laemmli buffer by heating $5 \mathrm{~min}$ at $95^{\circ} \mathrm{C}$, and then stored at $-20^{\circ} \mathrm{C}$.

For SVZ, RMS, and VCx, tissue was pooled from ten 3-month-old wildtype mice and were lysed by trituration (pipette and 26G syringe) in $10 \mu \mathrm{L}$ lysis buffer II (20 mM Tris $\mathrm{pH}$ $8,120 \mathrm{mM} \mathrm{NaCl}, 1 \% \mathrm{NP} 40,1 \mathrm{mM} \mathrm{MgCl} 2,5 \%$ glycerol, $1 \mathrm{X}$ protease/phosphatase inhibitor) per $\mathrm{mg}$ of tissue supplemented with $1 \mu \mathrm{L}$ of benzonase per $1 \mathrm{~mL}$ of lysis buffer II. Samples were processed as described above with $25 \mu \mathrm{L}$ of antibody-coupled beads. Pelleted beads were eluted in $30 \mu \mathrm{L}$ of laemmli buffer.

\subsection{Mass Spectrometry Analysis}

Proteomics analyses were performed by the Protein Mass Spectrometry Laboratory (Institut Curie, Paris, France). Eluted samples in laemmli were processed and resulting peptides were analyzed by nano-LC-MS/MS using an Ultimate 3000 system (Dionex, Thermo Fisher Scientific, Paris, France) coupled to an Orbitrap Fusion mass spectrometer (Q-OT-qIT, Thermo Fisher Scientific, Paris, France). Data were acquired using Xcalibur software and the resulting Mascot files (v2.5.1) were further processed by using myProMS software (v3.9) [63]. Percolator [64] was used for FDR calculations set to 1\% peptide level. For $\mathrm{ChP}$ proteomics, three experiments were performed $(N=3)$. For SVZ, RMS and VCx proteomics, one experiment was performed $(N=1)$.

\subsection{Ontology Analysis}

Genes with $>10$ mean reads in at least one of the ChP samples were selected for ontology analysis. Differentially expressed gene lists were generated by using threshold of $p$-adj $<0.05$. Ontology term enrichment and KEGG pathways were analyzed with DAVID Bioinformatic resource v6.7 $[65,66]$ and ontology terms were plotted as - $\log _{10}$ scale of the enrichment $p$-values. UniProt (access date 21 August 2020, http: / /www.uniprot.org) was used for obtaining func- 
tional classes (Tables 1, 3, 6 and 7). Gene list comparisons and Venn diagram data were generated with web-based tools (http:/ /www.bioinformatics.lu/venn.php).

\section{Conclusions}

The ChP has barrier functions for controlling what gets in and out of the brain, and homeostasis functions for controlling brain metabolites in the CSF. The data in this present study allow us to go a step further, by imparting important $\mathrm{ChP}$ endocrine functions that are putatively regulated by the cell-autonomous and non-cell-autonomous activities of OTX2. Indeed, in addition to regulating the expression and post-transcriptional modification of genes encoding signaling and hormone-transport proteins that are secreted into the CSF, such as Igf2 and Ttr, OTX2 itself is secreted by the ChP and exerts essential non-cellautonomous activities, such as the regulation of cerebral cortex plasticity or that of adult neurogenesis $[5,19,67]$. Transcriptomic analysis of different genetic Otx2 loss-of-function models, including conditional knockdown, specifically in the $\mathrm{ChP}$, coupled with proteomic analysis, are the first steps towards a better understanding of the molecular biology of this traveling transcription factor in and out of its main cerebral source.

Author Contributions: Conceptualization, A.P. (Anabelle Planques), V.O.M. and A.A.D.N.; methodology, A.P. (Anabelle Planques), V.O.M., C.B. (Clémence Bernard), C.B. (Corinne Blugeon), F.D., V.M. and A.A.D.N.; software, D.B. and L.J; validation, V.O.M., D.B., L.J., V.M. and A.A.D.N.; formal analysis, A.P. (Anabelle Planques), V.O.M. and A.A.D.N.; investigation, A.P. (Anabelle Planques), V.O.M., D.B., C.B. (Clémence Bernard), C.B. (Corinne Blugeon), F.D. and V.M.; resources, D.L. and A.P. (Alain Prochiantz).; data curation, A.P. (Anabelle Planques), V.O.M., D.B., L.J., V.M. and A.A.D.N.; writing —original draft preparation, A.A.D.N.; writing—review and editing, A.P. (Anabelle Planques), V.O.M., V.M., A.P. (Alain Prochiantz) and A.A.D.N.; visualization, A.A.D.N.; supervision, D.L., A.P. (Alain Prochiantz) and A.A.D.N.; project administration, A.A.D.N.; funding acquisition, A.P. (Alain Prochiantz). All authors have read and agreed to the published version of the manuscript.

Funding: This work was supported by the Région Ile-de-France DIM Cerveau et Pensée (to A.P. (Anabelle Planques)) and by the European Research Council (ERC-2013-ADG-339379 to A.P. (Alain Prochiantz)). The IBENS Genomics Core Facility was supported by the France Génomique national infrastructure, funded as part of the "Investissements d'Avenir" program managed by the Agence Nationale de la Recherche (ANR-10-INBS-09).

Institutional Review Board Statement: This research (project No. 00704.02) was approved by Ethics Committee $\mathrm{n}^{\circ} 59$ of the French Ministry for Research and Higher Education.

Informed Consent Statement: This work did not involve human subjects.

Data Availability Statement: RNA sequencing data are available with GEO accession GSE157386. Mass spectrometry data are available through the ProteomeXchange Consortium via the PRIDE repository with identifier PXD021244.

Acknowledgments: We wish to thank Namsuk Kim for help with tissue preparation.

Conflicts of Interest: The authors declare no conflict of interest.

\section{References}

1. Fame, R.M.; Lehtinen, M.K. Emergence and Developmental Roles of the Cerebrospinal Fluid System. Dev. Cell 2020, 52, 261-275. [CrossRef]

2. Johansson, P.A.; Irmler, M.; Acampora, D.; Beckers, J.; Simeone, A.; Götz, M. The transcription factor Otx2 regulates choroid plexus development and function. Development 2013, 140, 1055-1066. [CrossRef]

3. Lun, M.P.; Johnson, M.B.; Broadbelt, K.G.; Watanabe, M.; Kang, Y.J.; Chau, K.F.; Springel, M.W.; Malesz, A.; Sousa, A.M.M.; Pletikos, M.; et al. Spatially heterogeneous choroid plexus transcriptomes encode positional identity and contribute to regional CSF production. J. Neurosci. 2015, 35, 4903-4916. [CrossRef]

4. Dani, N.; Herbst, R.H.; McCabe, C.; Green, G.S.; Kaiser, K.; Head, J.P.; Cui, J.; Shipley, F.B.; Jang, A.; Dionne, D.; et al. A cellular and spatial map of the choroid plexus across brain ventricles and ages. Cell 2021, 184, 3056-3074.e21. [CrossRef]

5. Spatazza, J.; Lee, H.H.C.; Di Nardo, A.A.; Tibaldi, L.; Joliot, A.; Hensch, T.K.; Prochiantz, A. Choroid-Plexus-Derived Otx2 Homeoprotein Constrains Adult Cortical Plasticity. Cell Rep. 2013, 3, 1815-1823. [CrossRef] 
6. Rezsohazy, R. Non-transcriptional interactions of Hox proteins: Inventory, facts, and future directions. Dev. Dyn. 2014, 243, 117-131. [CrossRef]

7. Di Nardo, A.A.; Fuchs, J.; Joshi, R.L.; Moya, K.L.; Prochiantz, A. The physiology of homeoprotein transduction. Physiol. Rev. 2018, 98, 1943-1982. [CrossRef] [PubMed]

8. Di Nardo, A.A.; Joliot, A.; Prochiantz, A. Homeoprotein transduction in neurodevelopment and physiopathology. Sci. Adv. 2020, 6, eabc6374. [CrossRef] [PubMed]

9. Hoch, R.V.; Lindtner, S.; Price, J.D.; Rubenstein, J.L.R. OTX2 Transcription Factor Controls Regional Patterning within the Medial Ganglionic Eminence and Regional Identity of the Septum. Cell Rep. 2015, 12, 482-494. [CrossRef]

10. Rohde, K.; Hertz, H.; Rath, M.F. Homeobox genes in melatonin-producing pinealocytes: Otx2 and Crx act to promote hormone synthesis in the mature rat pineal gland. J. Pineal Res. 2019, 66, e12567. [CrossRef] [PubMed]

11. Zhang, J.; Zhang, M.; Acampora, D.; Vojtek, M.; Yuan, D.; Simeone, A.; Chambers, I. OTX2 restricts entry to the mouse germline. Nature 2018, 562, 595-599. [CrossRef]

12. Matsuda, K.; Mikami, T.; Oki, S.; Iida, H.; Andrabi, M.; Boss, J.M.; Yamaguchi, K.; Shigenobu, S.; Kondoh, H. ChIP-seq analysis of genomic binding regions of five major transcription factors in mouse epiblast stem cells that highlights a central role for ZIC2. Development 2017, 144, 1948-1958. [CrossRef] [PubMed]

13. Acampora, D.; Omodei, D.; Petrosino, G.; Garofalo, A.; Savarese, M.; Nigro, V.; di Giovannantonio, L.G.; Mercadante, V.; Simeone, A. Loss of the Otx2-Binding Site in the Nanog Promoter Affects the Integrity of Embryonic Stem Cell Subtypes and Specification of Inner Cell Mass-Derived Epiblast. Cell Rep. 2016, 15, 2651-2664. [CrossRef] [PubMed]

14. Samuel, A.; Housset, M.; Fant, B.; Lamonerie, T. Otx2 ChIP-seq reveals unique and redundant functions in the mature mouse retina. PLoS ONE 2014, 9, e89110. [CrossRef]

15. Fant, B.; Samuel, A.; Audebert, S.; Couzon, A.; El Nagar, S.; Billon, N.; Lamonerie, T. Comprehensive interactome of Otx2 in the adult mouse neural retina. Genesis 2015, 53, 685-694. [CrossRef]

16. Apulei, J.; Kim, N.; Testa, D.; Ribot, J.; Morizet, D.; Bernard, C.; Jourdren, L.; Blugeon, C.; di Nardo, A.A.; Prochiantz, A. Non-cell Autonomous OTX2 Homeoprotein Regulates Visual Cortex Plasticity Through Gadd45b/g. Cereb. Cortex 2019, 29, $2384-2395$. [CrossRef]

17. Sakai, A.; Nakato, R.; Ling, Y.; Hou, X.; Hara, N.; Iijima, T.; Yanagawa, Y.; Kuwano, R.; Okuda, S.; Shirahige, K.; et al. Genome-wide target analyses of Otx2 homeoprotein in postnatal cortex. Front. Neurosci. 2017, 11, 307. [CrossRef]

18. Peña, C.J.; Kronman, H.G.; Walker, D.M.; Cates, H.M.; Bagot, R.C.; Purushothaman, I.; Issler, O.; Loh, Y.-H.E.; Leong, T.; Kiraly, D.D.; et al. Early life stress confers lifelong stress susceptibility in mice via ventral tegmental area OTX2. Science 2017, 356, 1185-1188. [CrossRef] [PubMed]

19. Planques, A.; Oliveira Moreira, V.; Dubreuil, C.; Prochiantz, A.; Di Nardo, A.A. OTX2 Signals from the Choroid Plexus to Regulate Adult Neurogenesis. eNeuro 2019, 6. [CrossRef] [PubMed]

20. Sugiyama, S.; Di Nardo, A.A.; Aizawa, S.; Matsuo, I.; Volovitch, M.; Prochiantz, A.; Hensch, T.K. Experience-Dependent Transfer of Otx2 Homeoprotein into the Visual Cortex Activates Postnatal Plasticity. Cell 2008, 134, 508-520. [CrossRef] [PubMed]

21. Bernard, C.; Kim, H.T.; Torero Ibad, R.; Lee, E.J.; Simonutti, M.; Picaud, S.; Acampora, D.; Simeone, A.; Di Nardo, A.A.; Prochiantz, A.; et al. Graded Otx2 activities demonstrate dose-sensitive eye and retina phenotypes. Hum. Mol. Genet. 2014, 23, 1742-1753. [CrossRef]

22. Baruch, K.; Deczkowska, A.; David, E.; Castellano, J.M.; Miller, O.; Kertser, A.; Berkutzki, T.; Barnett-Itzhaki, Z.; Bezalel, D.; Wyss-Coray, T.; et al. Aging-induced type I interferon response at the choroid plexus negatively affects brain function. Science 2014, 346, 89-93. [CrossRef] [PubMed]

23. Silva-Vargas, V.; Maldonado-Soto, A.R.; Mizrak, D.; Codega, P.; Doetsch, F. Age-Dependent Niche Signals from the Choroid Plexus Regulate Adult Neural Stem Cells. Cell Stem Cell 2016, 19, 643-652. [CrossRef] [PubMed]

24. Lehtinen, M.K.; Zappaterra, M.W.; Chen, X.; Yang, Y.J.; Hill, A.D.; Lun, M.; Maynard, T.; Gonzalez, D.; Kim, S.; Ye, P.; et al. The Cerebrospinal Fluid Provides a Proliferative Niche for Neural Progenitor Cells. Neuron 2011, 69, 893-905. [CrossRef] [PubMed]

25. Bjornsson, C.S.; Apostolopoulou, M.; Tian, Y.; Temple, S. It takes a village: Constructing the neurogenic niche. Dev. Cell 2015, 32 , 435-446. [CrossRef]

26. Nguyen-Ba-Charvet, K.T.; Picard-Riera, N.; Tessier-Lavigne, M.; Baron-Van Evercooren, A.; Sotelo, C.; Chédotal, A. Multiple Roles for Slits in the Control of Cell Migration in the Rostral Migratory Stream. J. Neurosci. 2004, 24, 1497-1506. [CrossRef] [PubMed]

27. Sawamoto, K.; Wichterle, H.; Gonzalez-Perez, O.; Cholfin, J.A.; Yamada, M.; Spassky, N.; Murcia, N.S.; Garcia-Verdugo, J.M.; Marin, O.; Rubenstein, J.L.R.; et al. New neurons follow the flow of cerebrospinal fluid in the adult brain. Science 2006, 311, 629-632. [CrossRef]

28. Ziegler, A.N.; Schneider, J.S.; Qin, M.; Tyler, W.A.; Pintar, J.E.; Fraidenraich, D.; Wood, T.L.; Levison, S.W. IGF-II promotes stemness of neural restricted precursors. Stem Cells 2012, 30, 1265-1276. [CrossRef]

29. Falk, A.; Frisén, J. Amphiregulin is a mitogen for adult neural stem cells. J. Neurosci. Res. 2002, 69, 757-762. [CrossRef] [PubMed]

30. Jin, K.; Sun, Y.; Xie, L.; Batteur, S.; Mao, X.O.; Smelick, C.; Logvinova, A.; Greenberg, D.A. Neurogenesis and aging: FGF-2 and HB-EGF restore neurogenesis in hippocampus and subventricular zone of aged mice. Aging Cell 2003, 2, 175-183. [CrossRef]

31. Douet, V.; Kerever, A.; Arikawa-Hirasawa, E.; Mercier, F. Fractone-heparan sulphates mediate FGF-2 stimulation of cell proliferation in the adult subventricular zone. Cell Prolif. 2013, 46, 137-145. [CrossRef] 
32. Hayamizu, T.F.; Chan, P.T.; Johanson, C.E. FGF-2 immunoreactivity in adult rat ependyma and choroid plexus: Responses to global forebrain ischemia and intraventricular FGF-2. Neurol. Res. 2001, 23, 353-358. [CrossRef] [PubMed]

33. Tropepe, V.; Craig, C.G.; Morshead, C.M.; Van Kooy, D. Der Transforming growth factor- $\alpha$ null and senescent mice show decreased neural progenitor cell proliferation in the forebrain subependyma. J. Neurosci. 1997, 17, 7850-7859. [CrossRef]

34. Wachs, F.P.; Winner, B.; Couillard-Despres, S.; Schiller, T.; Aigner, R.; Winkler, J.; Bogdahn, U.; Aigner, L. Transforming growth factor- $\beta 1$ is a negative modulator of adult neurogenesis. J. Neuropathol. Exp. Neurol. 2006, 65, 358-370. [CrossRef] [PubMed]

35. Watson, D.J.; Passini, M.A.; Wolfe, J.H. Transduction of the choroid plexus and ependyma in neonatal mouse brain by vesicular stomatitis virus glycoprotein-pseudotyped lentivirus and adeno-associated virus type 5 vectors. Hum. Gene Ther. 2005, 16, 49-56. [CrossRef]

36. Arnaud, K.; Moreira, V.O.; Vincent, J.; Dallerac, G.; le Poupon, C.; Richter, M.; Müller, U.; Rondi-Reig, L.; Prochiantz, A.; di Nardo, A. Choroid plexus APP regulates adult brain proliferation and animal behavior. bioRxiv 2019. [CrossRef]

37. Sharma, M.; Khan, S.; Rahman, S.; Singh, L.R. The Extracellular Protein, Transthyretin Is an Oxidative Stress Biomarker. Front. Physiol. 2019, 10, 5. [CrossRef]

38. Terlecky, S.R. Peroxisomes, oxidative stress, and inflammation. World J. Biol. Chem. 2012, 3, 93. [CrossRef]

39. De Pablo, Y.; Nilsson, M.; Pekna, M.; Pekny, M. Intermediate filaments are important for astrocyte response to oxidative stress induced by oxygen-glucose deprivation and reperfusion. Histochem. Cell Biol. 2013, 140, 81-91. [CrossRef]

40. Kim, N.; Acampora, D.; Dingli, F.; Loew, D.; Simeone, A.; Prochiantz, A.; Di Nardo, A.A. Immunoprecipitation and mass spectrometry identify non-cell autonomous Otx2 homeoprotein in the granular and supragranular layers of mouse visual cortex. F1000Research 2014, 3, 178. [CrossRef] [PubMed]

41. Youn, J.Y.; Dyakov, B.J.A.; Zhang, J.; Knight, J.D.R.; Vernon, R.M.; Forman-Kay, J.D.; Gingras, A.C. Properties of Stress Granule and P-Body Proteomes. Mol. Cell 2019, 76, 286-294. [CrossRef]

42. Nédélec, S.; Foucher, I.; Brunet, I.; Bouillot, C.; Prochiantz, A.; Trembleau, A. Emx2 homeodomain transcription factor interacts with eukaryotic translation initiation factor 4E (eIF4E) in the axons of olfactory sensory neurons. Proc. Natl. Acad. Sci. USA 2004, 101, 10815-10820. [CrossRef]

43. Liu, X.; Shen, J.; Xie, L.; Wei, Z.; Wong, C.; Li, Y.; Zheng, X.; Li, P.; Song, Y. Mitotic Implantation of the Transcription Factor Prospero via Phase Separation Drives Terminal Neuronal Differentiation. Dev. Cell 2020, 52, 277-293.e8. [CrossRef] [PubMed]

44. Blaudin de Thé, F.; Rekaik, H.; Peze-Heidsieck, E.; Massiani-Beaudoin, O.; Joshi, R.L.; Fuchs, J.; Prochiantz, A. Engrailed homeoprotein blocks degeneration in adult dopaminergic neurons through LINE-1 repression. EMBO J. 2018, 37, e97374. [CrossRef]

45. Agoston, Z.; Schulte, D. Meis2 competes with the Groucho co-repressor Tle4 for binding to Otx2 and specifies tectal fate without induction of a secondary midbrain-hindbrain boundary organizer. Development 2009, 136, 3311-3322. [CrossRef]

46. Heimbucher, T.; Murko, C.; Bajoghli, B.; Aghaallaei, N.; Huber, A.; Stebegg, R.; Eberhard, D.; Fink, M.; Simeone, A.; Czerny, T. Gbx2 and Otx2 Interact with the WD40 Domain of Groucho/Tle Corepressors. Mol. Cell. Biol. 2007, 27, 340-351. [CrossRef]

47. McCartney, A.J.; Zhang, Y.; Weisman, L.S. Phosphatidylinositol 3,5-bisphosphate: Low abundance, high significance. BioEssays 2014, 36, 52-64. [CrossRef] [PubMed]

48. Topisirovic, I.; Kentsis, A.; Perez, J.M.; Guzman, M.L.; Jordan, C.T.; Borden, K.L.B. Eukaryotic Translation Initiation Factor 4E Activity Is Modulated by HOXA9 at Multiple Levels. Mol. Cell. Biol. 2005, 25, 1100-1112. [CrossRef] [PubMed]

49. Von Holst, A.; Egbers, U.; Prochiantz, A.; Faissner, A. Neural stem/progenitor cells express 20 tenascin C isoforms that are differentially regulated by Pax6. J. Biol. Chem. 2007, 282, 9172-9181. [CrossRef]

50. Balbinot, C.; Vanier, M.; Armant, O.; Nair, A.; Penichon, J.; Soret, C.; Martin, E.; Saandi, T.; Reimund, J.M.; Deschamps, J.; et al. Fine-tuning and autoregulation of the intestinal determinant and tumor suppressor homeobox gene CDX2 by alternative splicing. Cell Death Differ. 2017, 24, 2173-2186. [CrossRef]

51. Fossat, N.; Chatelain, G.; Brun, G.; Lamonerie, T. Temporal and spatial delineation of mouse Otx2 functions by conditional self-knockout. EMBO Rep. 2006, 7, 824-830. [CrossRef]

52. Acampora, D.; di Giovannantonio, L.G.; di Salvio, M.; Mancuso, P.; Simeone, A. Selective inactivation of Otx2 mRNA isoforms reveals isoform-specific requirement for visceral endoderm anteriorization and head morphogenesis and highlights cell diversity in the visceral endoderm. Mech. Dev. 2009, 126, 882-897. [CrossRef]

53. Chen, S.; Zhou, Y.; Chen, Y.; Gu, J. Fastp: An ultra-fast all-in-one FASTQ preprocessor. Bioinformatics 2018, 34, i884-i890. [CrossRef] [PubMed]

54. Patro, R.; Duggal, G.; Love, M.I.; Irizarry, R.A.; Kingsford, C. Salmon provides fast and bias-aware quantification of transcript expression. Nat. Methods 2017, 14, 417-419. [CrossRef] [PubMed]

55. Vitting-Seerup, K.; Sandelin, A. IsoformSwitchAnalyzeR: Analysis of changes in genome-wide patterns of alternative splicing and its functional consequences. Bioinformatics 2019, 35, 4469-4471. [CrossRef]

56. Vitting-Seerup, K.; Sandelin, A. The landscape of isoform switches in human cancers. Mol. Cancer Res. 2017, 15, 1206-1220. [CrossRef] [PubMed]

57. Anders, S.; Reyes, A.; Huber, W. Detecting differential usage of exons from RNA-seq data. Genome Res. 2012, $22,2008-2017$. [CrossRef]

58. Ritchie, M.E.; Phipson, B.; Wu, D.; Hu, Y.; Law, C.W.; Shi, W.; Smyth, G.K. Limma powers differential expression analyses for RNA-sequencing and microarray studies. Nucleic Acids Res. 2015, 43, e47. [CrossRef] [PubMed] 
59. Wang, L.; Park, H.J.; Dasari, S.; Wang, S.; Kocher, J.P.; Li, W. CPAT: Coding-potential assessment tool using an alignment-free logistic regression model. Nucleic Acids Res. 2013, 41, e74. [CrossRef] [PubMed]

60. Klausen, M.S.; Jespersen, M.C.; Nielsen, H.; Jensen, K.K.; Jurtz, V.I.; Sønderby, C.K.; Sommer, M.O.A.; Winther, O.; Nielsen, M.; Petersen, B.; et al. NetSurfP-2.0: Improved prediction of protein structural features by integrated deep learning. Prot. Struct. Funct. Bioinform. 2019, 87, 520-527. [CrossRef]

61. Almagro Armenteros, J.J.; Tsirigos, K.D.; Sønderby, C.K.; Petersen, T.N.; Winther, O.; Brunak, S.; von Heijne, G.; Nielsen, H. SignalP 5.0 improves signal peptide predictions using deep neural networks. Nat. Biotechnol. 2019, 37, 420-423. [CrossRef] [PubMed]

62. Finn, R.D.; Bateman, A.; Clements, J.; Coggill, P.; Eberhardt, R.Y.; Eddy, S.R.; Heger, A.; Hetherington, K.; Holm, L.; Mistry, J.; et al. Pfam: The protein families database. Nucleic Acids Res. 2014, 42, D222-D230. [CrossRef] [PubMed]

63. Poullet, P.; Carpentier, S.; Barillot, E. myProMS, a web server for management and validation of mass spectrometry-based proteomic data. Proteomics 2007, 7, 2553-2556. [CrossRef]

64. Spivak, M.; Weston, J.; Bottou, L.; Käll, L.; Noble, W.S. Improvements to the percolator algorithm for peptide identification from shotgun proteomics data sets. J. Proteome Res. 2009, 8, 3737-3745. [CrossRef]

65. Huang, D.W.; Sherman, B.T.; Lempicki, R.A. Systematic and integrative analysis of large gene lists using DAVID bioinformatics resources. Nat. Protoc. 2009, 4, 44-57. [CrossRef] [PubMed]

66. Huang, D.W.; Sherman, B.T.; Lempicki, R.A. Bioinformatics enrichment tools: Paths toward the comprehensive functional analysis of large gene lists. Nucleic Acids Res. 2009, 37, 1-13. [CrossRef]

67. Vincent, C.; Gilabert-Juan, J.; Gibel-Russo, R.; Alvarez-Fischer, D.; Krebs, M.-O.; Le Pen, G.; Prochiantz, A.; Di Nardo, A.A. Non-cell-autonomous OTX2 transcription factor regulates anxiety-related behavior in the mouse. Mol. Psychiatry $2021,1-12$. [CrossRef] 